\title{
Influence of biomass burning vapor wall loss correction on modeling organic aerosols in Europe by CAMx v6.50
}

\author{
Jianhui Jiang ${ }^{1}$, Imad El Haddad ${ }^{1}$, Sebnem Aksoyoglu ${ }^{1}$, Giulia Stefenelli ${ }^{1}$, Amelie Bertrand ${ }^{1,2}$, Nicolas Marchand ${ }^{2}$, \\ Francesco Canonaco ${ }^{1}$, Jean-Eudes Petit ${ }^{3}$, Olivier Favez $^{3}$, Stefania Gilardoni ${ }^{4}$, Urs Baltensperger ${ }^{1}$, and \\ André S. H. Prévôt ${ }^{1}$ \\ ${ }^{1}$ Laboratory of Atmospheric Chemistry, Paul Scherrer Institute, 5232 Villigen PSI, Switzerland \\ ${ }^{2}$ Aix Marseille Univ, CNRS, LCE, Marseille, France \\ ${ }^{3}$ Institut National de l'Environnement Industriel et des Risques (INERIS), Verneuil-en-Halatte, France \\ ${ }^{4}$ Italian National Research Council - Institute of Polar Sciences, Bologna, Italy
}

Correspondence: Imad El Haddad (imad.el-haddad@psi.ch), Sebnem Aksoyoglu (sebnem.aksoyoglu@psi.ch), and Jianhui Jiang (jianhui.jiang@psi.ch)

Received: 14 August 2020 - Discussion started: 4 September 2020

Revised: 7 February 2021 - Accepted: 17 February 2021 - Published: 24 March 2021

\begin{abstract}
Increasing evidence from experimental studies suggests that the losses of semi-volatile vapors to chamber walls could be responsible for the underestimation of organic aerosol (OA) in air quality models that use parameters obtained from chamber experiments. In this study, a box model with a volatility basis set (VBS) scheme was developed, and the secondary organic aerosol (SOA) yields with vapor wall loss correction were optimized by a genetic algorithm based on advanced chamber experimental data for biomass burning. The vapor wall loss correction increases the SOA yields by a factor of 1.9-4.9 and leads to better agreement with measured OA for 14 chamber experiments under different temperatures and emission loads. To investigate the influence of vapor wall loss correction on regional OA simulations, the optimized parameterizations (SOA yields, emissions of intermediate-volatility organic compounds from biomass burning, and enthalpy of vaporization) were implemented in the regional air quality model CAMx (Comprehensive Air Quality Model with extensions). The model results from the VBS schemes with standard (VBS_BASE) and vapor-wall-loss-corrected parameters (VBS_WLS), as well as the traditional two-product approach, were compared and evaluated by OA measurements from five Aerodyne aerosol chemical speciation monitor (ACSM) or aerosol mass spectrometer (AMS) stations in the winter of 2011. An additional reference scenario, VBS_noWLS, was also developed using the same parameterization as VBS_WLS ex-
\end{abstract}

cept for the SOA yields, which were optimized by assuming there is no vapor wall loss. The VBS_WLS generally shows the best performance for predicting OA among all OA schemes and reduces the mean fractional bias from $-72.9 \%$ (VBS_BASE) to $-1.6 \%$ for the winter OA. In Europe, the VBS_WLS produces the highest domain average OA in winter $\left(2.3 \mu \mathrm{g} \mathrm{m}^{-3}\right)$, which is $106.6 \%$ and $26.2 \%$ higher than VBS_BASE and VBS_noWLS, respectively. Compared to VBS_noWLS, VBS_WLS leads to an increase in SOA by up to $\sim 80 \%$ (in the Balkans). VBS_WLS also leads to better agreement between the modeled SOA fraction in OA (fSOA) and the estimated values in the literature. The substantial influence of vapor wall loss correction on modeled $\mathrm{OA}$ in Europe highlights the importance of further improvements in parameterizations based on laboratory studies for a wider range of chamber conditions and field observations with higher spatial and temporal coverage.

\section{Introduction}

Organic aerosol (OA) accounts for a substantial fraction of atmospheric particulate matter (Jimenez et al., 2009), which is closely associated with human health impacts and climate change (Cohen et al., 2017; Kanakidou et al., 2005; Lelieveld et al., 2015). Organic aerosol originates from a variety of natural and anthropogenic sources (Hallquist et al., 2009), 
among which residential biomass burning has been recognized as the dominant source for both primary (POA) and secondary (SOA) organic aerosols in Europe during wintertime (Butt et al., 2016; Jiang et al., 2019b; Qi et al., 2019). Despite its substantial contribution to OA, biomass burning OA is largely underestimated by chemical transport models (CTMs) (Ciarelli et al., 2017a; Hallquist et al., 2009; Robinson et al., 2007; Theodoritsi and Pandis, 2019; Woody et al., 2016).

Many efforts have been devoted to understanding and diminishing the gap between modeled and observed OA from biomass burning. One of the major reasons for underestimated OA is the absence of semi-volatile organic compounds (SVOCs) from residential biomass burning in the current emission inventories (Denier van der Gon et al., 2015). A smog chamber study showed that the precursors traditionally included in CTMs account for only $\sim 3 \%-27 \%$ of the observed SOA from residential biomass burning (Bruns et al., 2016). In order to compensate for the effects from missing precursors, various modeling studies have treated POA as semi-volatile and adopted different scaling approaches to calculate SVOC and IVOC emissions. The most commonly used method is to increase the POA emissions by a factor of 3 (Ciarelli et al., 2017a; Fountoukis et al., 2014; Jiang et al., 2019b; Tsimpidi et al., 2010), while recent studies have also developed new profiles based on nonmethane organic compounds (NMOCs) (Cai et al., 2019; Lu et al., 2018). However, an increasing number of laboratory experimental studies have found that SVOC and IVOC emissions have high variability depending on different burning conditions and fuel types (Hatch et al., 2015, 2017; Jen et al., 2019; Koss et al., 2018; Sekimoto et al., 2018), and the estimation of SVOCs and IVOCs in modeling studies remains to be improved. Meanwhile, increasing evidence from chamber experiments has demonstrated that losses of semi-volatile vapors to chamber walls could lead to a substantial underestimation of OA (Akherati et al., 2020; Bertrand et al., 2018; Bian et al., 2015; Krechmer et al., 2016; Loza et al., 2010; Matsunaga and Ziemann, 2010; Zhang et al., 2014). Unlike particle wall losses - which are routinely corrected in chamber studies - the effects of vapor wall losses are rarely investigated and considered in modeling practices.

Zhang et al. (2014) reported that vapor wall losses may lead to an underestimation of SOA by a factor of 1.1-4.2, depending on different $\mathrm{NO}_{x}$ conditions. This factor has been adopted by several CTM studies to scale up the yields of SOA. For instance, Baker et al. (2015) tested the sensitivity of CMAQ to vapor wall loss by increasing the yields of semi-volatile gases by a factor of 4 , with the traditional two-product approach used for OA simulations. This factor was also implemented in a box model with a volatility basis set (VBS) scheme (Hayes et al., 2015), which distributed organic species into logarithmically spaced volatility bins, and was shown to improve the model performance for predicting SOA (Donahue et al., 2011, 2006; Hodzic et al., 2010; Robin- son et al., 2007). Nevertheless, recent studies have shown that vapor wall losses lead to even larger variability in SOA yields according to different chamber conditions and precursor species (Akherati et al., 2019; Cappa et al., 2016). On the other hand, some studies took vapor wall loss corrections into account in CTMs using the SOA yields generated from the statistical oxidation model (SOM). Cappa et al. (2016) and Akherati et al. (2019) used the traditional twoproduct model to fit vapor-wall-loss-corrected SOA yields and applied the yields in the regional CTM UCD/CIT (University of California at Davis/California Institute of Technology). They reported, however, that the two-product fits might not be sufficiently robust. Furthermore, Hodzic et al. (2016) used a vapor-wall-loss-corrected VBS parameterization in the global model GEOS-Chem based on chamber experiments conducted on individual precursors, which are highly dependent on the experimental conditions. Each of these studies clearly called for a better assessment of the uncertainties across the entire range of precursor compounds as well as under different chamber conditions.

Here, we (1) developed a VBS-based box model and fit the vapor-wall-loss-corrected SOA yields of biomass burning IVOCs based on 14 chamber experiments under different temperature and emission loads, (2) implemented the vaporwall-loss-corrected VBS parameters in the regional chemical transport model Comprehensive Air Quality Model with extensions (CAMx), and (3) investigated the role of vapor wall loss correction in model performance by comparing modeled organic aerosols from traditional and modified VBS OA schemes with ambient observations at multiple European sites. Biomass burning in this study refers to residential biomass burning, while wildfires and prescribed burning are not included.

\section{Parameterization method}

\subsection{Chamber experimental data}

The parameterization of the VBS scheme was based on experimental data from two smog chamber campaigns in 20142015. It includes 14 experiments conducted under various temperature conditions $\left(-10,2,15^{\circ} \mathrm{C}\right)$ and covered a wide range of emission loads (from 19 to $284 \mu \mathrm{g} \mathrm{m}^{-3}$ ). Emissions were generated by combustion of beechwood in three different woodstoves, including conventional and modern burners, manufactured in 2002-2010. Beechwood is selected as it is one of the major forest types in Europe, and beechwood is widely used for residential heating and cooking in Europe. Although different biomass fuel types may largely affect the emitted organic gas species and affect SOA formation, a recent study showed that the effect of biomass fuel type on SOA formation is much smaller than the effects of initial organic mass $(\mathrm{OM})$ load and hydroxyl $(\mathrm{OH})$ radical exposure (Lim et al., 2019). The organic gases cover- 
ing 86 intermediate-volatility and semi-volatile organic compounds (IVOCs and SVOCs), which are SOA precursors, were measured by a proton-transfer-reaction time-of-flight mass spectrometer (PTR-ToF-MS). The PTR-ToF-MS was operated under standard conditions in $\mathrm{H}_{3} \mathrm{O}^{+}$mode, as introduced in Stefenelli et al. (2019). A common set of 263 ions was extracted from the measurements, and among these ions, 86 showed clear decay with time and were identified as potential SOA precursors. These are listed in Table S1 of Stefenelli et al. (2019). The aerosol evolution was monitored by a high-resolution time-of-flight aerosol mass spectrometer (HR-ToF-AMS). The particle wall loss has been corrected as described in Stefenelli et al. (2019). The conditions of each chamber experiment are shown in Table S1. A more detailed description of the experiments can be found in Stefenelli et al. (2019), Bertrand et al. (2017), and Bruns et al. (2016).

\subsection{VBS box model}

A VBS box model was developed to simulate the formation and evolution of primary and secondary $\mathrm{OA}$ in the chamber. In the model, we assumed that the condensable gases generated from oxidation of the precursors could (1) partition to the particle phase, (2) be lost on the chamber wall, and/or (3) be diluted by other gases injected into the smog chamber. CAMx includes four types of precursors from anthropogenic sources, i.e., toluene, xylene, benzene, and IVOCs, which includes all the other unspeciated organic gases. According to our measurements, the traditional anthropogenic precursors toluene, xylene, and benzene only account for $\sim 15 \%$ of the total organic gases. To facilitate the implementation of the optimized parameters in CAMx, all the measured SOA precursors including the traditional ones were lumped into one surrogate as IVOCs with the same reaction rate and volatility distribution. In comparison, Stefenelli et al. (2019) assigned the same set of compounds to six different classes according to their properties (reaction rates, expected SOA yields, etc.) as well as their origins and occurrence in the emissions. These included furans and methoxy-phenols from the pyrolysis of cellulose and lignin, respectively, single-ring and polyaromatic hydrocarbons from flaming combustion, and oxygenated non-aromatic compounds with fewer and more than six carbon atoms. The current lumping approach of all these species into one surrogate, despite variations in their properties, is more adapted for implementation into CAMx and for assessing vapor wall losses with additional parameters included in the box model. The organic compounds were distributed into six logarithmically spaced volatility bins corresponding to saturation concentrations of $10^{-1}, 10^{0}, 10^{1}, 10^{2}$, $10^{3}$, and $10^{4} \mu \mathrm{g} \mathrm{m}^{-3}$. The change in the organic gas concentration $(C)$ for a constituent within the volatility bin $i\left(C_{i}\right)$ can be described by Eq. (1), where $P$ is the production of organic gas $(\mathrm{OG})$ in the chamber due to oxidization of precursors, $k_{\mathrm{cs}}$ is the condensation sink $\left(\mathrm{s}^{-1}\right)$ describing the speed of condensable gases condensing on existing aerosol parti- cles, $k_{\mathrm{W}}$ is the rate constant of vapor lost to the wall, $k_{\mathrm{dil}}$ is the dilution rate, and $C_{\mathrm{eq}_{i, \mathrm{p}}}$ and $C_{\mathrm{eq}_{i, \mathrm{w}}}$ represent the gas-phase equilibrium concentrations to the aerosol particles and chamber wall surface, respectively:

$$
\begin{aligned}
\frac{\mathrm{d} C_{i}}{\mathrm{~d} t} & =P \cdot \zeta_{i}-k_{\mathrm{cs}}\left(C_{i}-C_{\mathrm{eq}_{i, \mathrm{p}}}\right) \\
& -k_{\mathrm{w}}\left(C_{i}-C_{\mathrm{eq}_{i, \mathrm{w}}}\right)-k_{\mathrm{dil}} \cdot C_{i} .
\end{aligned}
$$

The production rates of oxidized organic gases $(P)$ are used as inputs of the box model. They are determined by the consumption rates of precursors measured by PTR taking into account their dilution. $\zeta_{i}$ represents the mass fraction of primary and oxidation products in a volatility bin $i . \zeta_{i}$ of POA from biomass burning is obtained from May et al. (2013), with values of $0.2,0.1,0.1,0.2,0.1$, and 0.3 for compounds in each volatility bin. $\zeta_{i}$ of oxidation products is assumed to follow a kernel normal distribution as a function of $\log C^{*}, \zeta \sim$ $N\left(\mu, \sigma^{2}\right)$, where $\mu$ is the median value of $\log C^{*}$ and $\sigma$ is the standard deviation, which will be optimized as described in Sect. 2.3. The assumption of a normal distribution could ensure positive $\zeta_{i}$ values, allow constraining the total mass fraction of the certain surrogate to equal 1 , and reduce the model's degree of freedom significantly, as reported in Stefenelli et al. (2019). The time series of $k_{\text {dil }}$ is obtained from Stefenelli et al. (2019). The $k_{\mathrm{cs}}$ of each experiment is obtained from Bertrand et al. (2018). The $k_{\mathrm{w}}$ varies significantly depending on the chamber conditions such as the chamber size and relative humidity. Zhang et al. (2014) reported $k_{\mathrm{w}}$ values of $2.5 \times 10^{-4} \mathrm{~s}^{-1}$ and $1 \times 10^{-4} \mathrm{~s}^{-1}$ for toluene and other VOCs, respectively, while it is much higher in recent studies, such as $1.2 \times 10^{-3}$ to $2.4 \times 10^{-3} \mathrm{~s}^{-1}$ in Krechmer et al. (2016), $1.28 \times 10^{-3} \mathrm{~s}^{-1}$ in Akherati et al. (2020), and $\sim 1 \times 10^{-3}$ to $3.3 \times 10^{-3} \mathrm{~s}^{-1}$ in Bertrand et al. (2018). To cover the wide range of vapor wall loss, we tested three $k_{\mathrm{W}}$ values of $0.0020,0.0033$, and $0.0040 \mathrm{~s}^{-1}$ based on the conditions of our chamber. A base case was also developed by assuming there is no vapor wall loss in the chamber $\left(k_{\mathrm{w}}=0\right)$. The condensation of a species in the particle phase $\left(C_{\mathrm{p}}\right)$ can then be described by Eq. (2).

$$
\frac{\mathrm{d} C_{i, \mathrm{p}}}{\mathrm{d} t}=k_{\mathrm{cs}}\left(C_{i}-C_{\mathrm{eq}_{i, \mathrm{p}}}\right)-k_{\mathrm{dil}} \cdot C_{i, \mathrm{p}}
$$

Following the partitioning model of Pankow (1994), the gasphase concentrations at equilibrium with respect to the particle phase $\left(C_{\mathrm{eq}_{i, \mathrm{p}}}\right)$ and to the chamber wall $\left(C_{\mathrm{eq}_{i, \mathrm{w}}}\right)$ are determined by their partitioning coefficients $\xi_{i}$ and $\xi_{i, \mathrm{w}}$ (Donahue 
et al., 2009), as shown in Eqs. (3) and (4).

$$
\begin{aligned}
C_{\mathrm{eq}_{i, \mathrm{p}}} & =\left(C_{i, \mathrm{~g}}+C_{i, \mathrm{p}}\right) \cdot\left[1-\xi_{i}\right], \xi_{i}=\left(1+\frac{C_{i}^{*}}{C_{\mathrm{OA}}}\right)^{-1} \\
C_{\mathrm{eq}_{i, \mathrm{w}}} & =\left(C_{i, \mathrm{~g}}+C_{i, \mathrm{w}}\right) \cdot\left[1-\xi_{i, \mathrm{w}}\right], \\
\xi_{i, \mathrm{w}} & =\left(1+\frac{C_{i}^{*}}{C_{\mathrm{wall}}}\right)^{-1}
\end{aligned}
$$

Here, $C^{*}$ represents the saturation concentration, $C_{\mathrm{OA}}$ is the wall-loss-corrected OA concentration measured by the AMS, and $C_{\text {wall }}$ is the equivalent organic mass concentration at the wall determined in Bertrand et al. (2018). The ClausiusClapeyron equation (Eq. 5) was applied to take into account the effects of temperature on $C^{*}$ :

$C^{*}=C_{T 0}^{*} \cdot \frac{T_{0}}{T} \cdot \exp \left(\frac{\Delta H_{\mathrm{vap}} / 8.314}{1 / T_{0}-1 / T}\right)$,

where $C_{T 0}^{*}$ is the mass saturation concentration under the reference temperature $\left(T_{0}\right) . T$ is the temperature of each experiment, while $T_{0}$ equals $298 \mathrm{~K} . \Delta H_{\text {vap }}(\mathrm{J})$ is the enthalpy of vaporization at the reference temperature, and 8.314 is the universal gas constant $\left(\mathrm{J} \mathrm{mol}^{-1} \mathrm{~K}^{-1}\right) . \Delta H_{\text {vap }}=$ $\left\{70000-11000 \times \log C^{*}\right\}$ is adopted for the primary set (May et al., 2013), while $\Delta H_{\mathrm{vap}}$ of the oxidized products is determined during model optimization. The $C_{\text {wall }}$ was determined in previous studies to be of the order of a few milligrams per cubic meter $\left(\mathrm{mg} \mathrm{m}^{-3}\right.$; Bertrand et al., 2018). In this study, we run the box model for three different $C_{\text {wall }}$ values $\left(1,5,25 \mathrm{mg} \mathrm{m}^{-3}\right)$ with a reference temperature of $2{ }^{\circ} \mathrm{C}$ (275.15 K) according to Bertrand et al. (2018).

\subsection{Model optimization}

The model is optimized to constrain the volatility distribution (as a function of $\log C^{*}, \zeta \sim N\left(\mu, \sigma^{2}\right)$ ) and $\Delta H_{\text {vap }}$ of the oxidized products. A genetic algorithm (GA) is used to find the best-fit parameters leading to the lowest average root mean square error (RMSE) and mean bias (MB) between modeled and measured OA concentrations for all 14 experiments. The genetic algorithm is a metaheuristic algorithm inspired by the natural selection process to generate optimized solutions (Mitchell, 1996). It begins by creating an initial population of individual solutions (20 different combinations of $\mu, \sigma$, and $\Delta H_{\text {vap }}$ here) within certain upper and lower bounds, called parents. The performance of each solution is evaluated by a fitness function, which is the sum of RMSE and MB between the modeled and measured OA concentrations of 14 experiments in this study. A new generation of solutions is then formed either by making random changes to a single parent (called mutation) or by combining the vector entries of a pair of parents (called crossover). The process will be repeated until reaching the stopping conditions, which involves either the number of iterations reaching 50 or the stall generations (generation with no significant change in the fitness function) reaching 20. The GA is conducted using the genetic algorithm solver in the MATLAB R2019a Global Optimization Toolbox (The MathWorks, Inc).

\section{Modeling approach}

\subsection{Regional chemical transport model CAMx}

The regional model CAMx version 6.50 (Ramboll, 2018) was used to model organic aerosol in Europe $\left(15^{\circ} \mathrm{W}-35^{\circ} \mathrm{E}\right.$, $35-70^{\circ} \mathrm{N}$ ) for the whole year of 2011 , with a horizontal resolution of $0.25^{\circ} \times 0.125^{\circ}$ and 14 terrain-following vertical layers from $\sim 20 \mathrm{~m}$ above the ground up to $460 \mathrm{hPa}$. The Carbon Bond 6 Revision 2 (CB6r2) gas-phase mechanism (Hildebrandt Ruiz and Yarwood, 2013) was selected. The gas-aerosol partitioning of inorganic aerosols was simulated by the ISORROPIA thermodynamic model (Nenes et al., 1998). For organic aerosols, several OA schemes, including both the traditional two-product approach (SOA chemistry partitioning scheme, SOAP) and the VBS scheme with different parameterizations, were applied (see Sect. 3.2).

The meteorological parameters were prepared with the Weather Research and Forecasting model (WRF version 3.7.1; Skamarock et al., 2008) based on the $6 \mathrm{~h}$ European Centre for Medium-Range Weather Forecasts (ECMWF) reanalysis global data (Dee et al., 2011). The meteorological parameters were evaluated and reported in a previous study (Jiang et al., 2019a), which showed that most of the meteorological parameters met the criteria for meteorological model performance by Emery (2001). The initial and boundary conditions were obtained from the global model MOZART4/GEOS-5 (Horowitz et al., 2003). Inputs of ozone column densities were produced based on the Total Ozone Mapping Spectrometer (TOMS) data by the National Aeronautics and Space Administration (NASA, https://acd-ext.gsfc. nasa.gov/anonftp/toms/omi/data/Level3e/ozone/, last access: 17 March 2021), and the photolysis rates were then calculated by the Tropospheric Ultraviolet and Visible (TUV) Radiation Model version 4.8 (NCAR, 2011). The sourcespecific anthropogenic emissions were based on the European emission inventory TNO-MACC-III (Monitoring Atmospheric Composition and Climate) (Kuenen et al., 2014). The biogenic emissions (isoprene, monoterpenes, sesquiterpenes, soil NO) were simulated by the PSI model developed at the Laboratory of Atmospheric Chemistry at the Paul Scherrer Institute (Andreani-Aksoyoglu and Keller, 1995; Jiang et al., 2019a; Oderbolz et al., 2013). More details about the model inputs can be found in our previous studies performed using the same input data (Jiang et al., 2019a, b).

\subsection{Parameterization of OA schemes}

To investigate the effects of vapor-wall-loss-corrected yields and to compare to other modifications and/or parameterizations that are currently strongly debated in the community, 
Table 1. Description of the different OA schemes.

\begin{tabular}{|c|c|c|c|}
\hline OA scheme & IVOB $^{\mathrm{a}}$ emissions & $\begin{array}{l}k_{\mathrm{OH}} \text { for IVOB } \\
\left(\mathrm{cm}^{3} \mathrm{molec}^{-1} \mathrm{~s}^{-1}\right)\end{array}$ & $\begin{array}{l}\text { SOA yields for IVOB } \\
(\mathrm{ppm} / \mathrm{ppm})^{\mathrm{b}}\end{array}$ \\
\hline SOAP & 4.5.POA_BB & 1.34 & $/^{\mathrm{c}}$ \\
\hline VBS_BASE & & 4.0 & {$[0.081,0.135,0.800,0.604,0.0]$} \\
\hline VBS_3POA & & 4.0 & {$[0.081,0.135,0.800,0.604,0.0]$} \\
\hline VBS_noWLS & 12·POA_BB & 1.5 & {$[0.014,0.036,0.076,0.136,0.44]$} \\
\hline VBS_WLS & & 1.5 & {$[0.078,0.118,0.157,0.177,0.312]$} \\
\hline
\end{tabular}

five simulations with different OA schemes were conducted in this study (Table 1). Besides VBS_WLS, which uses the optimized parameterization with vapor wall loss correction for the biomass burning sector, SOAP and VBS_BASE represent the two standard parameterizations in CAMx; VBS_3POA represents a common approach to offset the missing SVOC emissions in recent modeling studies without vapor wall loss, and VBS_noWLS is another reference case without vapor wall loss, which uses exactly the same parameters as VBS_WLS except for the SOA yields from IVOCs. Details about each OA scheme are introduced below.

- SOAP. The SOAP (SOA chemistry partitioning) module is a semi-volatile equilibrium scheme based on the traditional two-product approach. POA emissions are assumed to be inert in SOAP. The updated parameterization of SOAP2.1 in CAMx v6.50 used the aerosol yield data that correct for vapor wall losses in smog chamber experiments based on Zhang et al. (2014).

- VBS_BASE. The VBS_BASE used the standard VBS parameterization in CAMx v6.50. The IVOC emissions from different sources were calculated based on the literature. IVOCs from gasoline and diesel vehicles were calculated as $25 \%$ and $20 \%$ of NMVOC emissions from gasoline and diesel vehicles, respectively (Jathar et al., 2014). IVOC emissions from residential biomass burning were estimated as 4.5 times POA emissions based on Ciarelli et al. (2017a). The IVOC emissions from other anthropogenic sources were calculated as 1.5 times POA as proposed by Robinson et al. (2007).

- VBS_3POA. An increasing number of experimental and modeling studies have reported a considerable contribution of semi-volatile organic compounds (SVOCs) to SOA formation (Bruns et al., 2016; Ciarelli et al., 2017b; Denier van der Gon et al., 2015; Hatch et al., 2017; Woody et al., 2015), while SVOCs are absent in the current emission inventories. Despite considerable variability of SVOC emissions from biomass burning according to recent studies, the VBS_3POA is sup- posed to be a reference case representing the commonly used approach without vapor wall loss, and therefore we adopted the routine approach of multiplying the POA emissions by a factor of 3 to offset the influence of missing SVOC emissions. This approach has been widely used in modeling studies (Ciarelli et al., 2016, 2017a; Shrivastava et al., 2011; Tsimpidi et al., 2010). All the other parameters were kept the same as the standard VBS parameterization in CAMx v6.50. The VBS_BASE IVOC emissions were adopted here.

- VBS_WLS. The VBS_WLS used the optimized parameters by the VBS box model, including the emissions and vapor-wall-loss-corrected yields for IVOCs from residential biomass burning, and the $\Delta H_{\mathrm{vap}}$ of the oxidized products. The modified parameters for volatility-bin-specific yields and $\Delta H_{\mathrm{vap}}$ of the oxidized products from IVOCs can be found at https://doi.org/10.5281/zenodo.3998342 (Jiang, 2020). The optimized mass yields in the box model were converted to molar yields using the default molecular weights in CAMx (Table 1). Both the optimized and default molar yields have a sum larger than 1 as the VBS scheme accounts for both oxygenation and fragmentation (Koo et al., 2014). The reaction rate with $\mathrm{OH}\left(k_{\mathrm{OH}}\right)$ was calculated based on the measurements following Stefenelli et al. (2019). Based on the chamber measurements, the IVOC emissions from residential biomass burning are $\sim 13.7$ times the primary $\mathrm{OM}$ load (Fig. S1), among which the traditional precursors in CAMx from biomass burning (toluene, xylene, and benzene) account for $\sim 15 \%$ of the total emissions. To avoid double counting of these traditional precursors, which are already included in the emission inventory, we applied a factor of 12 to calculate the IVOC emissions from biomass burning. The IVOC emissions from other sources were estimated by using the same approach as in VBS_3POA.

- VBS_noWLS. The VBS_noWLS was designed as a reference for VBS_WLS, which adopted the same pa- 
rameters as VBS_WLS except for the yields. The VBS_noWLS used the fitted yields from the box model assuming that there is no vapor wall loss $\left(k_{\mathrm{w}}=0\right)$.

\subsection{Model evaluation}

The general model performance for the major air pollutants $\left(\mathrm{SO}_{2}, \mathrm{NO}_{2}, \mathrm{O}_{3}, \mathrm{PM}_{2.5}\right)$ was reported in our previous study (Jiang et al., 2019b), which was comparable to other modeling studies in Europe. OA measurements and source apportionment studies using positive matrix factorization (PMF) analysis from five Aerodyne aerosol chemical speciation monitor (ACSM) or aerosol mass spectrometer (AMS) stations in the winter of 2011 were used to evaluate modeled primary and secondary organic aerosol by different OA schemes: Zurich (Canonaco et al., 2013), Marseille (Bozzetti et al., 2017), the SIRTA (Site Instrumental de Recherche par Télédétection Atmosphérique) facility located in the Paris region (Zhang et al., 2019), and Bologna and San Pietro Capofiume (SPC) (Paglione et al., 2020). For Zurich and SIRTA, only data collected from late autumn to early spring (January, February, March, November, and December) - when emissions from biomass burning are relatively high - were used for the statistical analysis, although the observations covered longer time periods. The spatial distribution and observation periods of each station are shown in Fig. S2. Statistical metrics, including mean bias (MB), mean error (ME), root mean square error (RMSE), mean fractional bias (MFB), and mean fractional error (MFE), between modeled and observed primary and secondary OA were calculated.

\section{Results and discussion}

\subsection{Modeled and measured OA from chamber experiments}

The optimized parameters were then applied to the box model to simulate OA production for 14 chamber experiments. Figure 1 shows the comparison between measured OA and modeled primary and secondary OA under the median chamber conditions $\left(k_{\mathrm{w}}=0.0033 \mathrm{~s}^{-1}, C_{\mathrm{wall}}=\right.$ $5 \mathrm{mg} \mathrm{m}^{-3}$ ) for each experiment. The model reproduces the process of OA formation for most of the experiments well, except for experiments no. 9 and no. 14, which have relatively lower OM loads (26 and $48 \mu \mathrm{g} \mathrm{m}^{-3}$ for Exp9 and Exp14, respectively). This can be partially explained by the different weighting impact for experiments with high or low OM loads. The experiments with higher OM loads normally have larger MB and RMSE at the beginning of optimization and therefore have a higher impact during the model optimization. A direct consequence is that the optimized parameters would work better for experiments with higher OM loads. However, the model performance in each experiment could also be influenced by a series of other factors such as temperature and chamber conditions. While the model simulation without vapor wall loss correction largely overestimates $\mathrm{OA}$ at the initial time point and underestimates the final OA (Fig. S3), the agreement between the modeled and measured trends improved when the vapor wall loss was taken into account. The mean bias (MB) and root mean square error (RMSE) between the modeled and observed OA in 14 experiments are 6.7 and $42.2 \mu \mathrm{g} \mathrm{m}^{-3}$ for the case under median chamber conditions, which are $48 \%$ and $12 \%$ lower than in the case without vapor loss correction $(\mathrm{MB}=-12.8$, $47.8 \mathrm{\mu g} \mathrm{m}^{-3}$ ). To investigate the role of vapor wall loss in modeled OA, another set of simulations was performed in which we used the same optimized parameterization under the median chamber conditions but set $k_{\mathrm{w}}=0$. In these cases, the modeled OA concentrations (dashed line in Fig. 1) were based on the assumption that there is no vapor wall loss. The wall loss ratio $R_{\text {wall }}$, which is defined as the ratio between the modeled OA concentration without $\left(k_{\mathrm{W}}=0\right)$ and with $\left(k_{\mathrm{w}}=0.0033 \mathrm{~s}^{-1}, C_{\mathrm{wall}}=5 \mathrm{mg} \mathrm{m}^{-3}\right)$ vapor wall loss, was calculated for the end point of each experiment (Fig. 1c). The $R_{\text {wall }}$ values varied from 1.5 (Exp2) to 3.2 (Exp11) among the 14 experiments and showed a clear dependence on the initial OA loads.

To further understand the factors influencing $R_{\text {wall }}$, we conducted a series of model simulations with and without vapor wall loss under different initial organic mass loads, temperature, and condensation sink inputs (Fig. 2). Higher $k_{\mathrm{w}}$ and $C_{\text {wall }}$ lead to higher $R_{\text {wall }}$ values for all the cases, and different chamber conditions $\left(k_{\mathrm{w}}, C_{\mathrm{w}}\right)$ could result in a different $R_{\text {wall }}$ by a factor of 1.2-1.6, depending on different temperature, OM loads, and condensation sinks. The $R_{\text {wall }}$ values generally decrease with increasing initial OM loads, which is consistent with the fact that $R_{\text {wall }}$ values for Exp8-14 are higher than Exp1-7. The increased $R_{\text {wall }}$ with the increasing temperature explains why Exp10 through $\operatorname{Exp} 14\left(T=15^{\circ} \mathrm{C}\right)$ have higher $R_{\text {wall }}$ than $\operatorname{Exp} 8$ and $\operatorname{Exp} 9\left(T=-10^{\circ} \mathrm{C}\right)$, while they have similar OM load levels. The condensation sink is inversely correlated with $R_{\text {wall }}$, indicating that the higher the rate of condensable gases condensing on the existing particles, the lower the vapor loss to the chamber wall, and therefore the lower the effect of vapor wall loss on modeled OA.

The optimized volatility distribution for the secondary condensable gases from biomass burning (ppm per ppm IVOC) based on different wall loss assumptions $\left(k_{\mathrm{w}}>0\right.$ or $\left.k_{\mathrm{w}}=0\right)$ is displayed in Fig. 3a. The optimized yields considering vapor wall loss lead to a 3.3 times higher mass in the low-volatility bins $\left(\log C^{*} \leq 0\right)$ compared to that assuming $k_{\mathrm{w}}=0$, indicating significant effects of vapor wall loss correction on predicting SOA production. To give a more direct view of the effects of vapor wall loss on the SOA yield, we integrated the mass of SOA for all the volatility bins at $298 \mathrm{~K}$ (Fig. 3b). The mass yield under the median chamber conditions for vapor wall loss $\left(k_{\mathrm{w}}=0.0033 \mathrm{~s}^{-1}, C_{\text {wall }}=\right.$ $5 \mathrm{mg} \mathrm{m}^{-3}$ ) is higher than the base case without considering the vapor wall loss about by factors of 4.9 (when $C_{\mathrm{OA}}=$ 

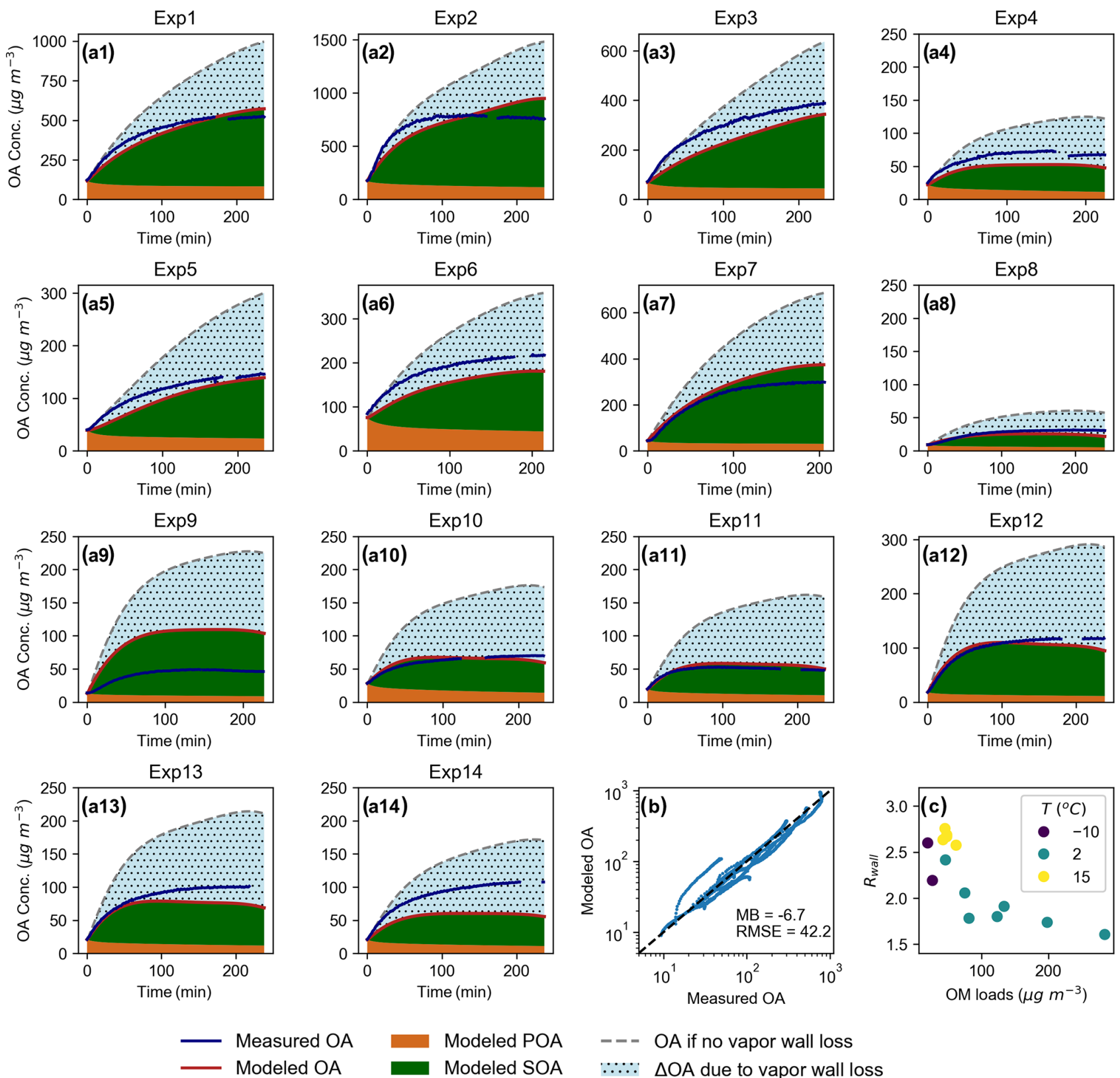

--- OA if no vapor wall loss
$\cdots \cdots$

Figure 1. Comparison between measured and modeled OA with an optimized parameterization under $k_{\mathrm{W}}=0.0033 \mathrm{~s}^{-1}$ and $C_{\mathrm{wall}}=$ $5 \mathrm{mg} \mathrm{m}^{-3}$ (a, b). Relation between the end-point wall loss factor $R_{\text {wall }}$ of each experiment and initial OM loads under different temperature (c). The gray dashed lines in (a) represent modeled OA with the same parameterization but $k_{\mathrm{W}}=0$.

$0.1 \mu \mathrm{g} \mathrm{m}^{-3}$ ) to 1.9 (when $C_{\mathrm{OA}}=1000 \mu \mathrm{g} \mathrm{m}^{-3}$ ). The influence of vapor wall loss on mass yield decreases with decreasing temperature. At $0{ }^{\circ} \mathrm{C}$, the mass yield with vapor wall loss correction is higher than the base case by factors of 4.3 (when $C_{\mathrm{OA}}=0.1 \mu \mathrm{g} \mathrm{m}^{-3}$ ) to 1.7 (when $C_{\mathrm{OA}}=1000 \mu \mathrm{g} \mathrm{m}^{-3}$ ).

\subsection{Performance of CAMx with different $\mathrm{OA}$ schemes}

The modeled OA concentrations with different OA schemes were compared with measurements from five ACSM/AMS stations in winter. The statistical results are shown in Table 2, and the distributions of OA concentrations and the mean bias between modeled and measured primary and secondary OA are displayed in Fig. 4. OA is underestimated overall with all OA schemes. The VBS schemes lead to a better model performance than the two-product approach SOAP, except for VBS_BASE with the default VBS parameterization. These results are consistent with a previous study using CAMx (Meroni et al., 2017), in which the better performance of SOAP compared to the default VBS was reported as a result 

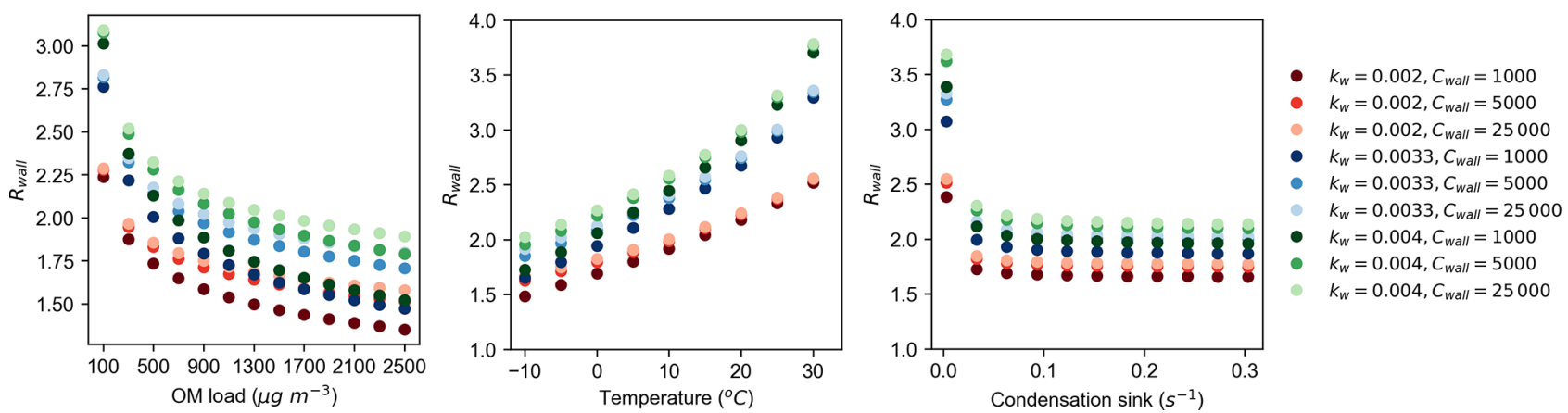

Figure 2. Dependence of the wall loss factor $R_{\mathrm{wall}}\left(C_{\mathrm{OA}, k_{\mathrm{w}}=0} / C_{\mathrm{OA}}\right.$, optimal $\left.k_{\mathrm{w}}\right)$ on initial organic mass load, temperature, and condensation sink.
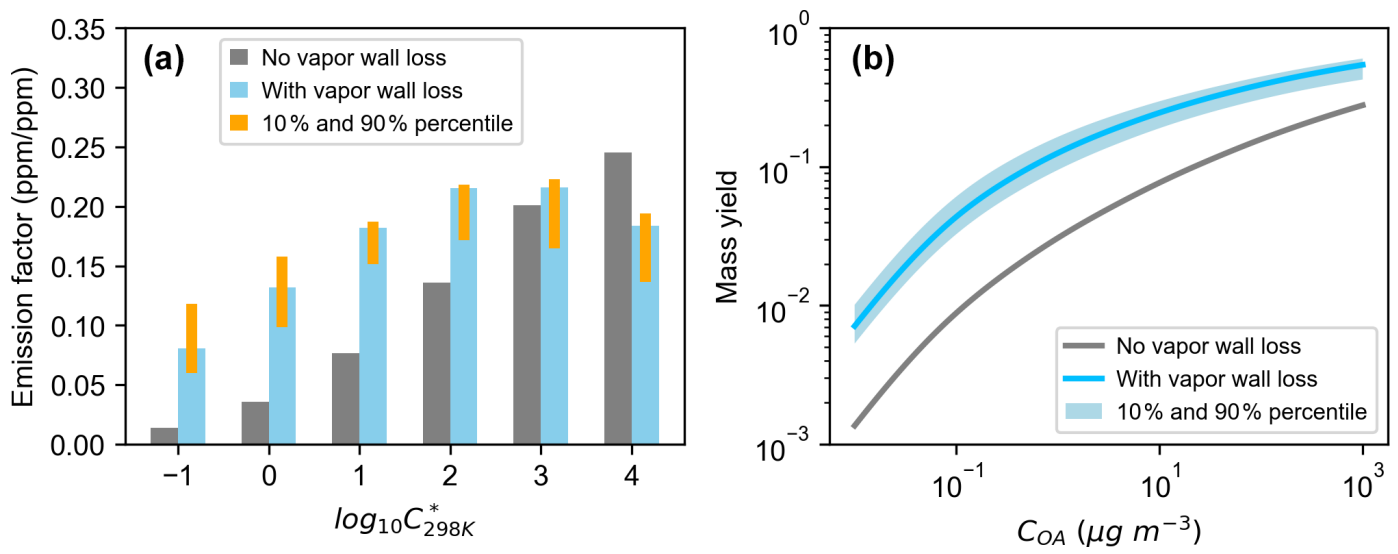

Figure 3. Optimized yield factors (a) and the mass yield of SOA from biomass burning at $298 \mathrm{~K}$ (b) with and without vapor wall loss correction. The blue bars (a) and line (b) with vapor wall loss refer to median chamber conditions with $k_{\mathrm{W}}=0.0033 \mathrm{~s}-1$ and $C_{\mathrm{wall}}=$ $5 \mathrm{mg} \mathrm{m}^{-3}$.

of error compensation. The improved performance of modified VBS (3POA, noWLS, WLS) for OA mainly comes from the contribution of SOA (Table 2). The modeled SOA by 3POA and noWLS is very similar, and therefore the analysis below will focus on the comparison between noWLS and WLS, for which the only difference is that WLS uses vaporwall-loss-corrected yields for IVOCs from biomass burning, while noWLS uses the fitted yields assuming no vapor wall loss $\left(k_{\mathrm{w}}=0\right)$. WLS reduces the MFB between the modeled and measured SOA from $52.5 \%$ in noWLS to $20.0 \%$. WLS shows a better average MB than noWLS; however, it also increases the upper whisker of the MB (Fig. 4b), largely affected by overestimated SOA in Bologna and SPC.

Limited by the availability of OA measurements, the effects of vapor wall loss correction on model performance present a clear site dependence in this study. The modeled and measured daily average OA concentrations at each site are shown in Fig. 5. The temporal variations of primary and secondary OA at these sites can be found in Fig. S4. VBS_WLS leads to the best performance for both OA and SOA in Marseille and SIRTA, in spite of an overall underestimation (Fig. S4b, c). In Zurich, the vapor-wall-loss- corrected yields for biomass burning improve the model performance in February and March, while there is an overestimation of OA and SOA for all the OA schemes in November (Fig. S4a). The largest contribution to OA during this period was found to be from biogenic SOA, which was potentially overestimated due to overestimated temperatures during the same time period (Jiang et al., 2019b). Bologna and SPC are located in the Po Valley where biomass burning contributes most to winter OA (Jiang et al., 2019b), and therefore higher effects from vapor wall loss correction on SOA are observed compared to other sites. At SPC, fog scavenging processes played an important role in OA during the measurements (Gilardoni et al., 2014); however, the meteorological model failed to reproduce the fog events due to the coarse resolution in this study (Jiang et al., 2019b). Consequently, both VBS_WLS and noWLS lead to an overestimation of OA and SOA, while SOAP and VBS_BASE show better performance, probably due to compensation for errors (Fig. S4e). In Bologna, a significant overestimation of temperature was found on 2 to 6 December (Jiang et al., 2019b), leading to a significant underestimation of SOA for all the OA schemes (Fig. S4d). Excluding this period, the mod- 
Table 2. Statistical results for model performance in simulating OA, SOA, and POA. The number of daily average observations from five ACSM/AMS stations is 216.

\begin{tabular}{llrrrrrr}
\hline Species & OA scheme & $\begin{array}{r}\text { MB } \\
\left(\mu \mathrm{g} \mathrm{m}^{-3}\right)\end{array}$ & $\begin{array}{r}\text { ME } \\
\left(\mu \mathrm{g} \mathrm{m}^{-3}\right)\end{array}$ & $\begin{array}{r}\text { RMSE } \\
\left(\mu \mathrm{g} \mathrm{m}^{-3}\right)\end{array}$ & $\begin{array}{r}\text { MFB } \\
(\%)\end{array}$ & $\begin{array}{r}\text { MFE } \\
(\%)\end{array}$ & $r$ \\
\hline \multirow{2}{*}{ OA } & SOAP & -4.1 & 4.9 & 7.2 & -44.3 & 65.3 & 0.38 \\
& VBS_BASE & -4.9 & 5.6 & 7.9 & -72.9 & 83.3 & 0.29 \\
& VBS_3POA & -1.6 & 4.3 & 6.5 & -12.4 & 51.7 & 0.42 \\
& VBS_noWLS & -1.9 & 4.3 & 6.5 & -17.4 & 52.7 & 0.41 \\
& VBS_WLS & -0.4 & 4.6 & 6.9 & -1.6 & 52.2 & 0.41 \\
\hline \multirow{2}{*}{ SOA } & SOAP & -2.3 & 3.1 & 4.3 & -77.8 & 98.3 & 0.12 \\
& VBS_BASE & -1.6 & 2.8 & 4.1 & -63.0 & 90.6 & 0.22 \\
& VBS_3POA & -1.2 & 2.8 & 4.1 & -51.1 & 84.3 & 0.23 \\
& VBS_noWLS & -1.3 & 2.8 & 4.0 & -52.5 & 84.9 & 0.24 \\
& VBS_WLS & 0.2 & 3.2 & 4.6 & -20.0 & 76.4 & 0.26 \\
\hline \multirow{2}{*}{ POA } & SOAP & -0.7 & 1.9 & 3.1 & 4.4 & 56.7 & 0.49 \\
& VBS_BASE & -2.3 & 2.5 & 4.0 & -64.1 & 81.5 & 0.44 \\
& VBS_3POA & 0.8 & 2.4 & 3.4 & 36.3 & 64.2 & 0.45 \\
& VBS_noWLS & 0.4 & 2.2 & 3.2 & 30.1 & 61.9 & 0.45 \\
& VBS_WLS & 0.6 & 2.3 & 3.3 & 32.4 & 62.5 & 0.45 \\
\hline
\end{tabular}
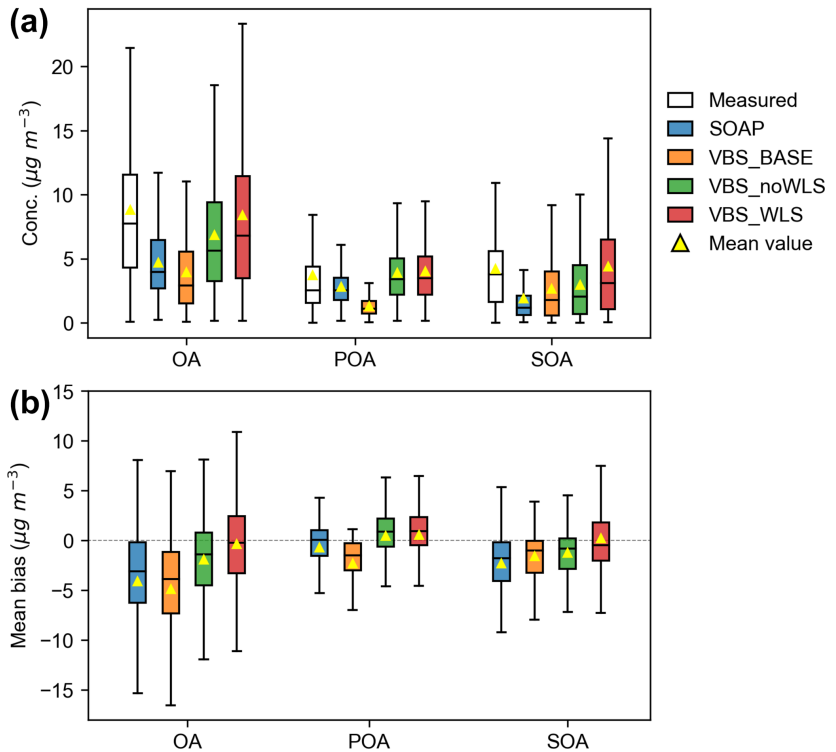

Figure 4. Concentrations of measured and modeled OA, POA, and SOA at five ACSM or AMS stations in winter (a) and mean bias for different OA schemes (b). The lines inside boxes represent median values, and the yellow triangles represent mean values.

eled SOA by VBS_WLS is $89 \%$ higher than the measurements, while the modeled SOA concentrations by the other schemes are closer to the measurements, with relative differences of $-64 \%$ for SOAP, $-10 \%$ for VBS_BASE, and $4 \%$ for VBS_noWLS.

The distinct performance of vapor-wall-loss-corrected VBS at different sites could arise from various factors. It might come from the high uncertainties of SVOC and IVOC emissions from biomass burning, which were estimated by the same factor for the whole domain but were reported to have substantial inter-country variations (Denier van der Gon et al., 2015). Missing formation and removal processes such as photolytic and heterogeneous oxidation in the model could also result in different model performance for specific sites. In addition, in spite of the advanced chamber measurements we used to optimize the yield parameters covering a wide range of precursor species and multiple temperature and chamber conditions, the fitted vapor-wall-loss-corrected parameterization is still highly uncertain. To achieve a more robust parameterization and to further improve the model performance for OA, more studies on SVOC and IVOC emissions, as well as the formation and removal mechanisms of SOA based on extensive laboratory studies and field observations with higher spatial and temporal coverage, are needed.

\subsection{Effects of vapor wall loss correction on modeled OA in Europe}

\subsubsection{OA}

The modeled OA results in Europe for the whole year of 2011 with different OA schemes were compared to investigate the effects of OA schemes and the vapor wall loss correction. Among all the sources, residential biomass burning contributed $16.3 \%-52.6 \% \mathrm{POA}$ and $5.9 \%-28.9 \%$ SOA in winter (Jiang et al., 2019b), indicating the potential roles of vapor wall loss for the biomass burning sector. Figure 6 shows the modeled OA, SOA, and POA in winter (DecemberJanuary-February). VBS_WLS leads to the highest domain average OA $\left(2.3 \mu \mathrm{g} \mathrm{m}^{-3}\right)$, which is $16.4 \%, 26.2 \%, 38.7 \%$, and $106.6 \%$ higher than VBS_3POA, VBS_noWLS, SOAP, 

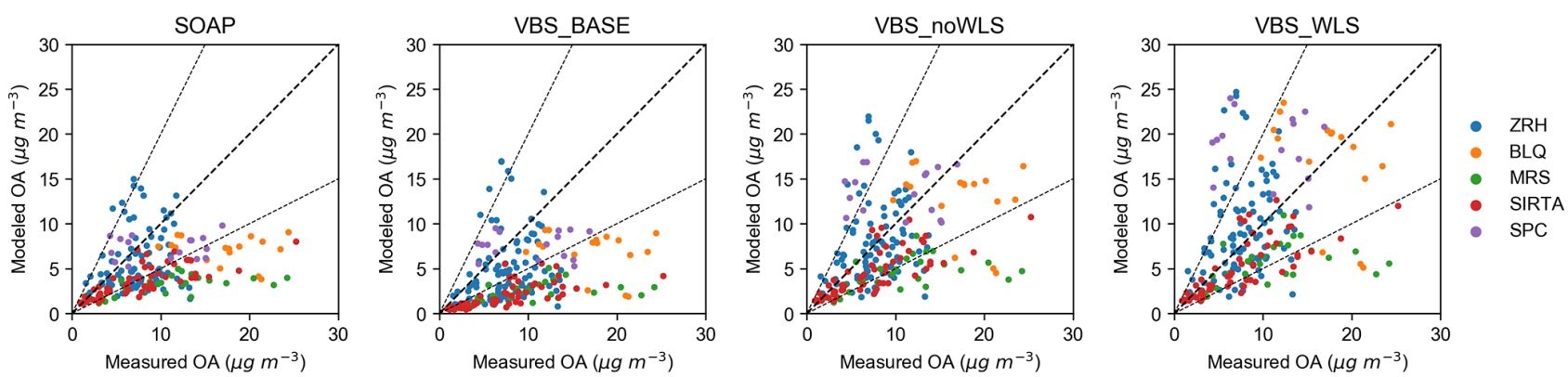

Figure 5. Measured and modeled daily average OA using different OA schemes in winter. ZRH: Zurich, BLQ: Bologna, MRS: Marseille, SIRTA: Paris SIRTA, SPC: San Pietro Capofiume.

and VBS_BASE, respectively. The VBS schemes generally produce higher OA than SOAP, except for the default parameterization (VBS_BASE) in which the lack of SVOC emissions is not considered. However, SOAP leads to the second highest SOA after VBS_WLS, especially in northern Europe where monoterpene emissions from coniferous forests are relatively high. This is mostly because of the high terpene SOA yields in SOAP2.1, which were reduced in the later version of the CAMx model (CAMx v7.0, http://www. camx.com, last access: 17 March 2021). The vapor-wallloss-corrected yields lead to increased SOA in large areas of central and southern Europe (Fig. 7). The largest difference is predicted for the Po Valley and Romania regions with a high residential biomass burning impact (Fig. S5). The overall relative differences between VBS_WLS and VBS_noWLS are more than $80 \%$, and the highest grid-scale increment reaches $5.6 \mu \mathrm{g} \mathrm{m}^{-3}$ in the region of the Balkans. The modeled POA concentrations are similar to those in the VBS case with correction for SVOC (3POA, noWLS, WLS), with domain average concentrations ranging from 0.9 (noWLS) to $1.1(3 \mathrm{POA}) \mu \mathrm{g} \mathrm{m}^{-3}$, and therefore no significant effects were observed from vapor wall loss correction (Fig. 6). The POA simulated by VBS_BASE $\left(0.3 \mu \mathrm{g} \mathrm{m}^{-3}\right)$ is even lower than $\operatorname{SOAP}\left(0.7 \mu \mathrm{g} \mathrm{m}^{-3}\right)$, as POA is semi-volatile and could evaporate and react with oxidants to form secondary products in VBS, while SOAP assumes POA to be inert.

The effects of different VBS schemes on OA are much smaller in summer (Fig. S6). Despite a slight increase from the VBS_BASE $\left(1.2 \mu \mathrm{g} \mathrm{m}^{-3}\right)$, the modeled OA by the three modified VBS schemes is quite similar (1.4$\left.1.5 \mu \mathrm{g} \mathrm{m}^{-3}\right)$. The effects of vapor-wall-loss-corrected yields for biomass burning emissions are negligible due to low emissions in summer (Fig. S7). SOAP produced the highest $\mathrm{OA}\left(2.1 \mu \mathrm{g} \mathrm{m}^{-3}\right)$ in summer due to the high SOA yields from monoterpenes as explained before.

\subsubsection{Fraction of $\mathrm{SOA}$ in $\mathrm{OA}$}

The effects of the updated VBS schemes on the fraction of annual average SOA in total $\mathrm{OA}(\mathrm{fSOA}=\mathrm{SOA} / \mathrm{OA})$ are shown in Fig. 8. The VBS schemes lead to a higher fSOA (domain average $71.4 \%-87.3 \%$ ) compared to SOAP (domain average $69.9 \%$ ) in most of the domain except for northern Europe, where SOAP produces high biogenic SOA. The increased POA emissions to offset the missing SVOC emissions (3POA, noWLS, WLS) decrease the fSOA compared to the default VBS parameterization (BASE), while the vapor wall loss correction yields (WLS) result in $\sim 5.8 \%$ higher fSOA than noWLS for the domain average, and the largest grid-scale increase reaches $43.4 \%$ in the Balkans. The absolute differences between FSOA for WLS and noWLS are relatively higher in rural areas than urban areas, where fSOA is lower due to high primary emissions.

The modeled fSOA values were compared with measurements from previous studies in Europe (Crippa et al., 2014; Jiang et al., 2019b). The measured fSOA from the literature covered 18 sites and different seasons between 2008 and 2011 (Table S2). SOAP tends to underestimate the fSOA, while VBS_BASE significantly overpredicts the fSOA (Fig. 9). Both WLS and noWLS tend to underestimate the high fSOA and overestimate the low fSOA. VBS_WLS has $5 \%$ higher fSOA than VBS_noWLS and shows the highest agreement on the range of fSOA with the measurements and the average fSOA values (measured: 69.6\%; VBS_WLS: $69.1 \%$ ). The largest improvements occur in winter when the vapor-wall-loss-corrected yields of biomass burning emissions largely increase the SOA production.

\section{Conclusions}

In this study, we optimized the SOA yields for a VBS-based box model using 14 chamber experiments with biomass burning and implemented the fitted VBS parameters (SOA yields, IVOC emissions from biomass burning, and enthalpy of vaporization) in the regional air quality model CAMx v6.5. The influence of the vapor wall loss correction on the model performance was investigated by comparing modeled primary and secondary OA with traditional and modified OA schemes, including the two-product approach (SOAP), the standard VBS (VBS_BASE), VBS with 3 times the POA to compensate for the missing SVOCs (VBS_3POA), VBS 

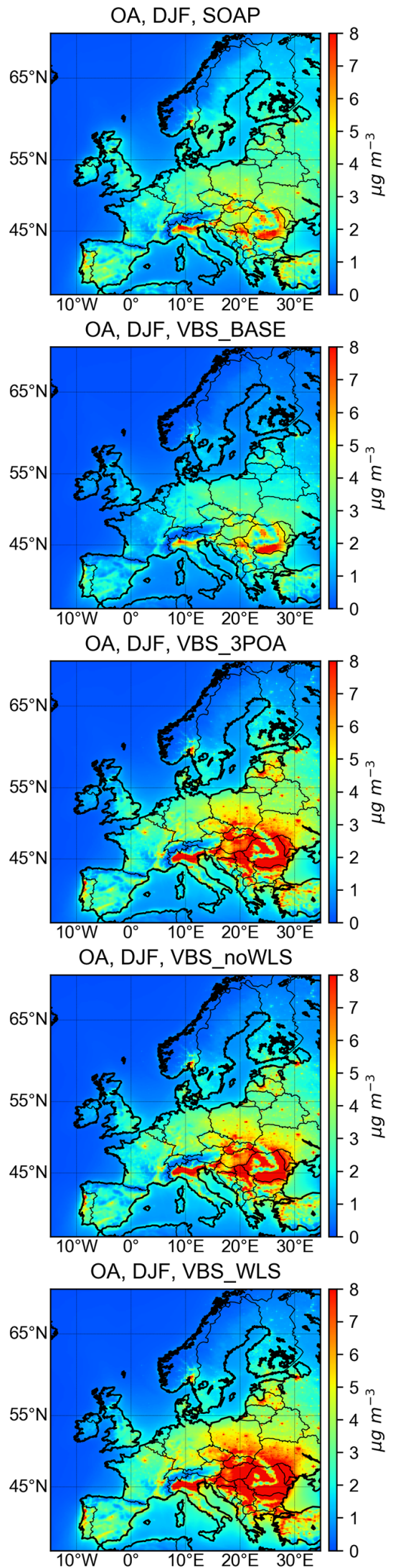
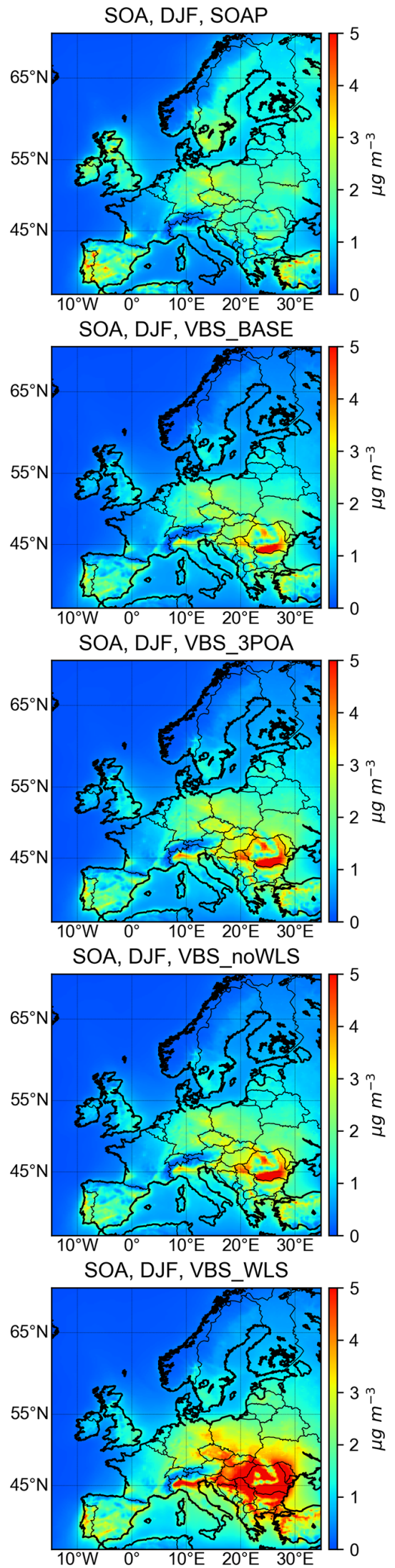
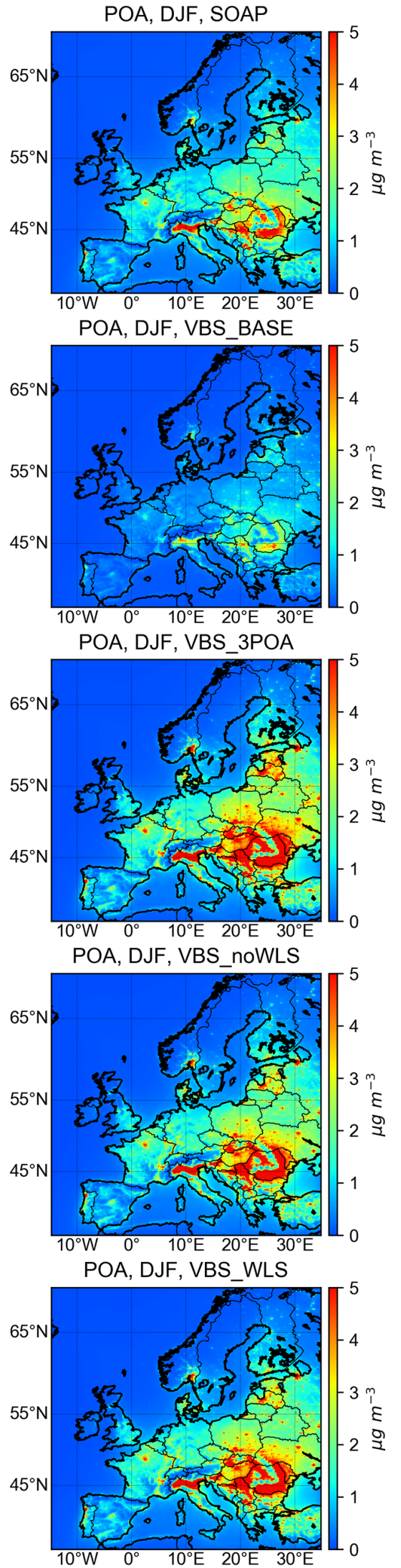

Figure 6. Modeled OA, SOA, and POA in winter (DJF, December-January-February) by different OA schemes. 

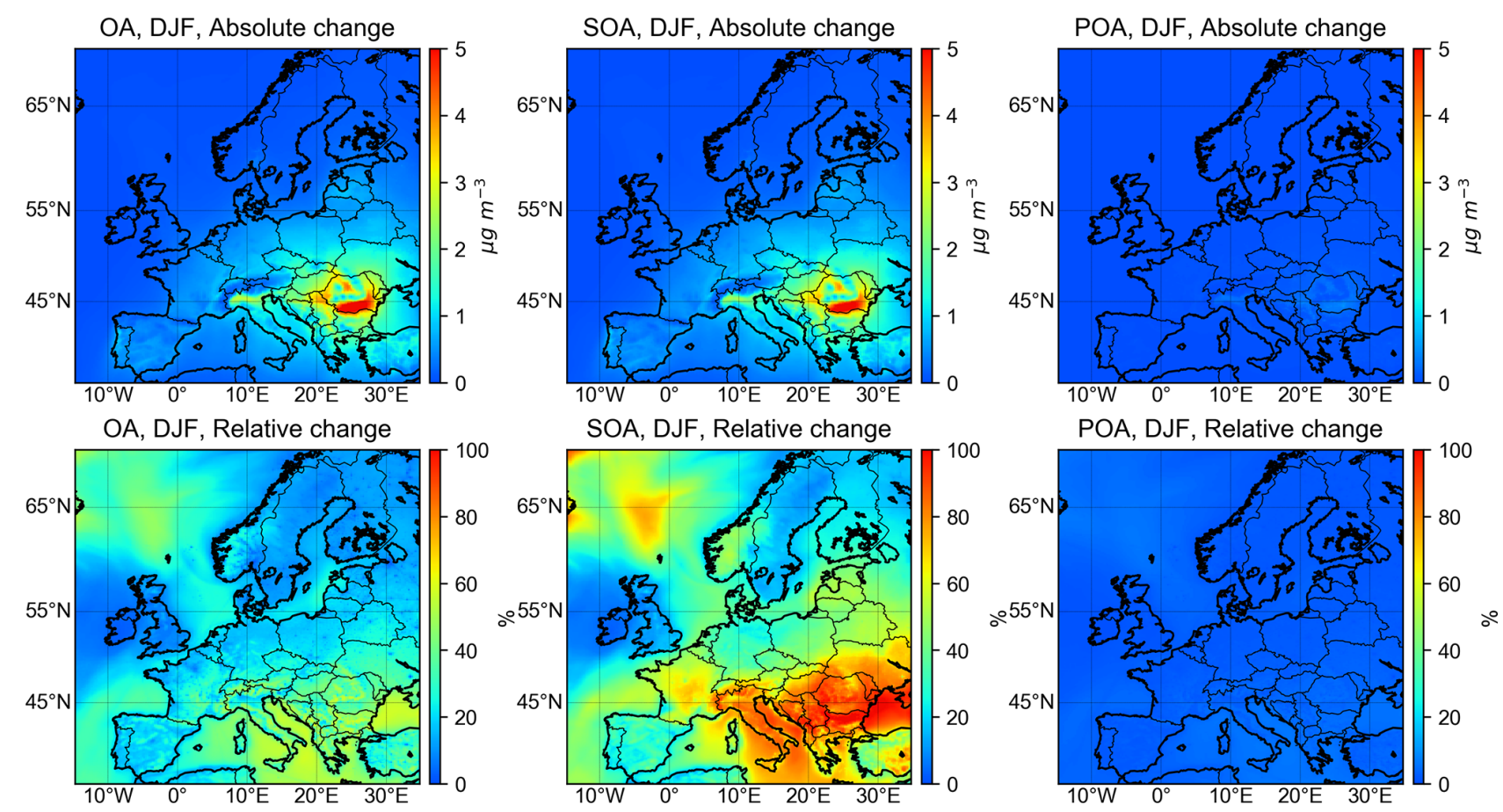

Figure 7. Differences in modeled OA, SOA, and POA in winter (DJF, December-January-February) by VBS schemes with (VBS_WLS) and without (VBS_noWLS) vapor wall corrections.
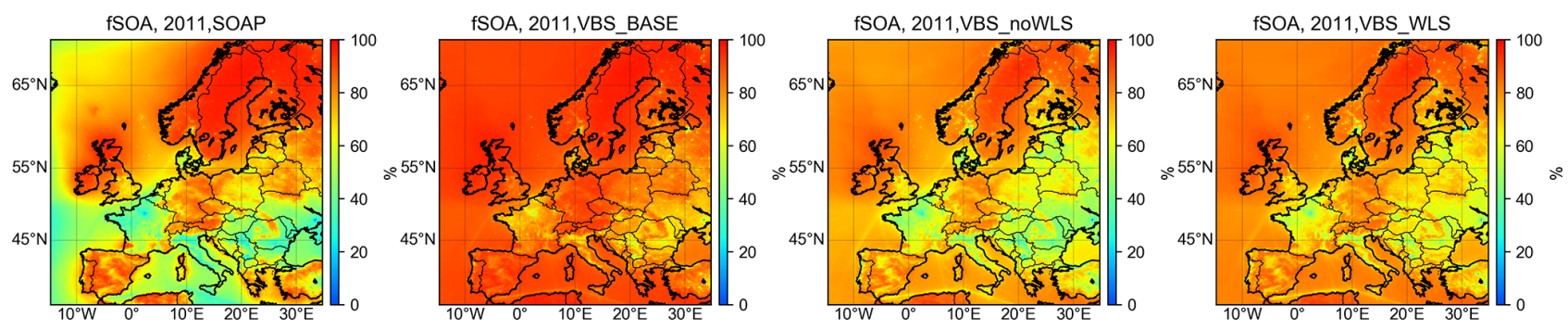

Figure 8. Modeled fractions of annual mean SOA to total OA (fSOA) using different OA schemes. Modeled results for VBS_3POA are very similar to VBS_noWLS and are therefore not shown here.

with vapor wall loss correction (VBS_WLS), and an additional reference scenario with the same parameterizations as in VBS_WLS except for using the default SOA yields from biomass burning IVOCs (VBS_noWLS).

The vapor wall loss correction increases the mass distributed in the low-volatility bins $\left(\log C^{*} \leq 0\right)$ by a factor of 4.3 and increases the SOA yields by a factor of $1.9-4.9$ (at $298 \mathrm{~K}$ ). Comparison of the modeled results with different OA schemes to field measurements from five ACSM/AMS stations in Europe in winter suggests that VBS_WLS generally has the best performance to predict OA, which lowers the highest mean fractional bias from $-72.9 \%$ (VBS_BASE) to $-1.6 \%$ for OA and from $-77.8 \%$ (SOAP) to $20.0 \%$ for SOA. In Europe, the VBS_WLS produces the highest domain average $\mathrm{OA}$ in winter $\left(2.3 \mu \mathrm{g} \mathrm{m}^{-3}\right)$, which is $106.6 \%$ and $26.2 \%$ higher than VBS_BASE and VBS_noWLS, re- spectively. The largest influence of vapor wall loss correction was predicted in Romania where the VBS_WLS increases SOA by $\sim 80 \%$ compared to VBS_noWLS due to high emissions from residential biomass burning. VBS_WLS also leads to the highest agreement with measurements for the SOA fraction in OA (fSOA) from the literature.

The optimized parameterization with vapor wall loss correction in this study is expected to provide some insight to improve SOA underestimation in CTMs. Despite the overall improvement of model performance for predicting SOA, the VBS_WLS was found to increase the mean bias at specific sites compared to noWLS. To achieve a more robust parameterization and to further improve the model performance, complementary studies on SVOC and IVOC emissions, as well as on the formation and removal mechanisms of SOA 


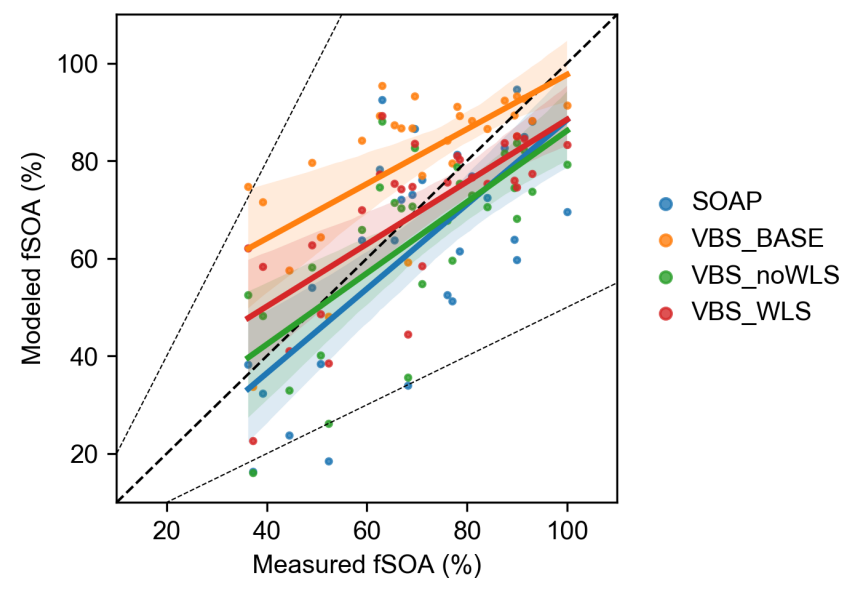

Figure 9. Comparison between modeled and measured fSOA from the literature over the year (see data and sources in Table S2). The shading indicates the confidence intervals of the regression lines.

based on extensive laboratory studies and field observations with higher spatial and temporal coverage, are still needed.

Code and data availability. The source code of the standard CAMx model is available at the RAMBOLL website (http://www.camx.com, last access: 17 March 2021). The modified CAMx codes and the source code of the MATLAB-based VBS box model are available online at https://doi.org/10.5281/zenodo.3998342 (Jiang, 2020). Data in the figures are available at https://doi.org/10.5281/zenodo.4267890 (Jiang, 2021).

Supplement. The supplement related to this article is available online at: https://doi.org/10.5194/gmd-14-1681-2021-supplement.

Author contributions. JJ and IEH conceived the study. JJ carried out the model simulation and data analysis. GS and AB conducted the chamber measurements. NM, FC, JEP, OF, and SG provided the measurement data. SA, ASHP, and UB supervised the entire work development. The paper was prepared by JJ. All authors discussed and contributed to the final paper.

Competing interests. The authors declare that they have no conflict of interest.

Acknowledgements. We are grateful to the European Centre for Medium-Range Weather Forecasts (ECMWF) for the meteorological data, the National Aeronautics and Space Administration (NASA) and its data-contributing agencies (NCAR, UCAR) for the TOMS and MODIS data, the global air quality model data, and the TUV model. We thank RAMBOLL for support with CAMx. Simulations with WRF and CAMx models were performed at the Swiss
National Supercomputing Centre (CSCS). We thank the Aerosol, Clouds and Trace gases Research InfraStructure (ACTRIS) and the Chemical On-Line cOmpoSition and Source Apportionment of fine aerosoL (COLOSSAL) cost action (CA16109) for support and harmonization within OA measurements and data treatments.

Financial support. This research has been supported by the Schweizerischer Nationalfonds zur Förderung der Wissenschaftlichen Forschung (grant no. 200021_169787) and the European Union's Horizon 2020 research and innovation program through the EUROCHAMP-2020 Infrastructure Activity (grant no. 730997$)$.

Review statement. This paper was edited by Christoph Knote and reviewed by two anonymous referees.

\section{References}

Akherati, A., Cappa, C. D., Kleeman, M. J., Docherty, K. S., Jimenez, J. L., Griffith, S. M., Dusanter, S., Stevens, P. S., and Jathar, S. H.: Simulating secondary organic aerosol in a regional air quality model using the statistical oxidation model - Part 3: Assessing the influence of semi-volatile and intermediatevolatility organic compounds and $\mathrm{NO}_{x}$, Atmos. Chem. Phys., 19, 4561-4594, https://doi.org/10.5194/acp-19-4561-2019, 2019.

Akherati, A., He, Y., Coggon, M. M., Koss, A. R., Hodshire, A. L., Sekimoto, K., Warneke, C., de Gouw, J., Yee, L., Seinfeld, J. H., Onasch, T. B., Herndon, S. C., Knighton, W. B., Cappa, C. D., Kleeman, M. J., Lim, C. Y., Kroll, J. H., Pierce, J. R., and Jathar, S. H.: Oxygenated aromatic compounds are important precursors of secondary organic aerosol in biomass-burning emissions, Environ. Sci. Technol., 54, 85688579, https://doi.org/10.1021/acs.est.0c01345, 2020.

Andreani-Aksoyoglu, S. and Keller, J.: Estimates of monoterpene and isoprene emissions from the forests in Switzerland, J. Atmos. Chem., 20, 71-87, https://doi.org/10.1007/bf01099919, 1995.

Baker, K. R., Carlton, A. G., Kleindienst, T. E., Offenberg, J. H., Beaver, M. R., Gentner, D. R., Goldstein, A. H., Hayes, P. L., Jimenez, J. L., Gilman, J. B., de Gouw, J. A., Woody, M. C., Pye, H. O. T., Kelly, J. T., Lewandowski, M., Jaoui, M., Stevens, P. S., Brune, W. H., Lin, Y.-H., Rubitschun, C. L., and Surratt, J. D.: Gas and aerosol carbon in California: comparison of measurements and model predictions in Pasadena and Bakersfield, Atmos. Chem. Phys., 15, 5243-5258, https://doi.org/10.5194/acp15-5243-2015, 2015.

Bertrand, A., Stefenelli, G., Bruns, E. A., Pieber, S. M., TemimeRoussel, B., Slowik, J. G., Prevot, A. S. H., Wortham, H., El Haddad, I., and Marchand, N.: Primary emissions and secondary aerosol production potential from woodstoves for residential heating: Influence of the stove technology and combustion efficiency, Atmos. Environ., 169, 65-79, https://doi.org/10.1016/j.atmosenv.2017.09.005, 2017.

Bertrand, A., Stefenelli, G., Pieber, S. M., Bruns, E. A., TemimeRoussel, B., Slowik, J. G., Wortham, H., Prévôt, A. S. H., El Haddad, I., and Marchand, N.: Influence of the vapor wall loss on the degradation rate constants in chamber experiments of lev- 
oglucosan and other biomass burning markers, Atmos. Chem. Phys., 18, 10915-10930, https://doi.org/10.5194/acp-18-109152018, 2018.

Bian, Q., May, A. A., Kreidenweis, S. M., and Pierce, J. R.: Investigation of particle and vapor wall-loss effects on controlled wood-smoke smog-chamber experiments, Atmos. Chem. Phys., 15, 11027-11045, https://doi.org/10.5194/acp-15-110272015, 2015.

Bozzetti, C., El Haddad, I., Salameh, D., Daellenbach, K. R., Fermo, P., Gonzalez, R., Minguillón, M. C., Iinuma, Y., Poulain, L., Elser, M., Müller, E., Slowik, J. G., Jaffrezo, J.-L., Baltensperger, U., Marchand, N., and Prévôt, A. S. H.: Organic aerosol source apportionment by offline-AMS over a full year in Marseille, Atmos. Chem. Phys., 17, 8247-8268, https://doi.org/10.5194/acp-17-8247-2017, 2017.

Bruns, E. A., El Haddad, I., Slowik, J. G., Kilic, D., Klein, F., Baltensperger, U., and Prévôt, A. S. H.: Identification of significant precursor gases of secondary organic aerosols from residential wood combustion, Sci. Rep.-UK, 6, 27881, https://doi.org/10.1038/srep27881, 2016.

Butt, E. W., Rap, A., Schmidt, A., Scott, C. E., Pringle, K. J., Reddington, C. L., Richards, N. A. D., Woodhouse, M. T., RamirezVillegas, J., Yang, H., Vakkari, V., Stone, E. A., Rupakheti, M., S. Praveen, P., G. van Zyl, P., P. Beukes, J., Josipovic, M., Mitchell, E. J. S., Sallu, S. M., Forster, P. M., and Spracklen, D. V.: The impact of residential combustion emissions on atmospheric aerosol, human health, and climate, Atmos. Chem. Phys., 16, 873-905, https://doi.org/10.5194/acp-16-873-2016, 2016.

Cai, S., Zhu, L., Wang, S., Wisthaler, A., Li, Q., Jiang, J., and Hao, J.: Time-resolved intermediate-volatility and semivolatile organic compound emissions from household coal combustion in Northern China, Environ. Sci. Technol., 53, 9269-9278, https://doi.org/10.1021/acs.est.9b00734, 2019.

Canonaco, F., Crippa, M., Slowik, J. G., Baltensperger, U., and Prévôt, A. S. H.: SoFi, an IGOR-based interface for the efficient use of the generalized multilinear engine (ME2) for the source apportionment: ME-2 application to aerosol mass spectrometer data, Atmos. Meas. Tech., 6, 3649-3661, https://doi.org/10.5194/amt-6-3649-2013, 2013.

Cappa, C. D., Jathar, S. H., Kleeman, M. J., Docherty, K. S., Jimenez, J. L., Seinfeld, J. H., and Wexler, A. S.: Simulating secondary organic aerosol in a regional air quality model using the statistical oxidation model - Part 2: Assessing the influence of vapor wall losses, Atmos. Chem. Phys., 16, 3041-3059, https://doi.org/10.5194/acp-16-3041-2016, 2016.

Ciarelli, G., Aksoyoglu, S., Crippa, M., Jimenez, J.-L., Nemitz, E., Sellegri, K., Äijälä, M., Carbone, S., Mohr, C., O’Dowd, C., Poulain, L., Baltensperger, U., and Prévôt, A. S. H.: Evaluation of European air quality modelled by CAMx including the volatility basis set scheme, Atmos. Chem. Phys., 16, 10313-10332, https://doi.org/10.5194/acp-16-10313-2016, 2016.

Ciarelli, G., Aksoyoglu, S., El Haddad, I., Bruns, E. A., Crippa, M., Poulain, L., Äijälä, M., Carbone, S., Freney, E., O’Dowd, C., Baltensperger, U., and Prévôt, A. S. H.: Modelling winter organic aerosol at the European scale with CAMx: evaluation and source apportionment with a VBS parameterization based on novel wood burning smog chamber experiments, Atmos. Chem. Phys., 17, 7653-7669, https://doi.org/10.5194/acp17-7653-2017, 2017a.
Ciarelli, G., El Haddad, I., Bruns, E., Aksoyoglu, S., Möhler, O., Baltensperger, U., and Prévôt, A. S. H.: Constraining a hybrid volatility basis-set model for aging of wood-burning emissions using smog chamber experiments: a box-model study based on the VBS scheme of the CAMx model (v5.40), Geosci. Model Dev., 10, 2303-2320, https://doi.org/10.5194/gmd-102303-2017, 2017b.

Cohen, A. J., Brauer, M., Burnett, R., Anderson, H. R., Frostad, J., Estep, K., Balakrishnan, K., Brunekreef, B., Dandona, L., Dandona, R., Feigin, V., Freedman, G., Hubbell, B., Jobling, A., Kan, H., Knibbs, L., Liu, Y., Martin, R., Morawska, L., Pope, C. A., Shin, H., Straif, K., Shaddick, G., Thomas, M., van Dingenen, R., van Donkelaar, A., Vos, T., Murray, C. J. L., and Forouzanfar, M. H.: Estimates and 25-year trends of the global burden of disease attributable to ambient air pollution: an analysis of data from the Global Burden of Diseases Study 2015, Lancet, 389, 1907-1918, https://doi.org/10.1016/s0140-6736(17)30505-6, 2017.

Crippa, M., Canonaco, F., Lanz, V. A., Äijälä, M., Allan, J. D., Carbone, S., Capes, G., Ceburnis, D., Dall'Osto, M., Day, D. A., DeCarlo, P. F., Ehn, M., Eriksson, A., Freney, E., Hildebrandt Ruiz, L., Hillamo, R., Jimenez, J. L., Junninen, H., Kiendler-Scharr, A., Kortelainen, A.-M., Kulmala, M., Laaksonen, A., Mensah, A. A., Mohr, C., Nemitz, E., O’Dowd, C., Ovadnevaite, J., Pandis, S. N., Petäjä, T., Poulain, L., Saarikoski, S., Sellegri, K., Swietlicki, E., Tiitta, P., Worsnop, D. R., Baltensperger, U., and Prévôt, A. S. H.: Organic aerosol components derived from 25 AMS data sets across Europe using a consistent ME-2 based source apportionment approach, Atmos. Chem. Phys., 14, 61596176, https://doi.org/10.5194/acp-14-6159-2014, 2014.

Dee, D. P., Uppala, S. M., Simmons, A. J., Berrisford, P., Poli, P., Kobayashi, S., Andrae, U., Balmaseda, M. A., Balsamo, G., Bauer, P., Bechtold, P., Beljaars, A. C. M., van de Berg, L., Bidlot, J., Bormann, N., Delsol, C., Dragani, R., Fuentes, M., Geer, A. J., Haimberger, L., Healy, S. B., Hersbach, H., Holm, E. V., Isaksen, L., Kallberg, P., Kohler, M., Matricardi, M., McNally, A. P., Monge-Sanz, B. M., Morcrette, J. J., Park, B. K., Peubey, C., de Rosnay, P., Tavolato, C., Thepaut, J. N., and Vitart, F.: The ERA-Interim reanalysis: configuration and performance of the data assimilation system, Q. J. Roy. Meteor. Soc., 137, 553-597, https://doi.org/10.1002/qj.828, 2011.

Denier van der Gon, H. A. C., Bergström, R., Fountoukis, C., Johansson, C., Pandis, S. N., Simpson, D., and Visschedijk, A. J. H.: Particulate emissions from residential wood combustion in Europe - revised estimates and an evaluation, Atmos. Chem. Phys., 15, 6503-6519, https://doi.org/10.5194/acp15-6503-2015, 2015.

Donahue, N. M., Robinson, A. L., Stanier, C. O., and Pandis, S. N.: Coupled partitioning, dilution, and chemical aging of semivolatile organics, Environ. Sci. Technol., 40, 2635-2643, https://doi.org/10.1021/es052297c, 2006.

Donahue, N. M., Robinson, A. L., and Pandis, S. N.: Atmospheric organic particulate matter: From smoke to secondary organic aerosol, Atmos. Environ., 43, 94-106, https://doi.org/10.1016/j.atmosenv.2008.09.055, 2009.

Donahue, N. M., Epstein, S. A., Pandis, S. N., and Robinson, A. L.: A two-dimensional volatility basis set: 1 . organic-aerosol mixing thermodynamics, Atmos. Chem. Phys., 11, 3303-3318, https://doi.org/10.5194/acp-11-3303-2011, 2011. 
Emery, C.: Enhanced Meteorological Modeling and Performance Evaluation for Two Texas Ozone Episodes, ENVIRON International Corporation, Novato, California, USA, 2001.

Fountoukis, C., Megaritis, A. G., Skyllakou, K., Charalampidis, P. E., Pilinis, C., Denier van der Gon, H. A. C., Crippa, M., Canonaco, F., Mohr, C., Prévôt, A. S. H., Allan, J. D., Poulain, L., Petäjä, T., Tiitta, P., Carbone, S., Kiendler-Scharr, A., Nemitz, E., O’Dowd, C., Swietlicki, E., and Pandis, S. N.: Organic aerosol concentration and composition over Europe: insights from comparison of regional model predictions with aerosol mass spectrometer factor analysis, Atmos. Chem. Phys., 14, 9061-9076, https://doi.org/10.5194/acp-14-9061-2014, 2014.

Gilardoni, S., Massoli, P., Giulianelli, L., Rinaldi, M., Paglione, M., Pollini, F., Lanconelli, C., Poluzzi, V., Carbone, S., Hillamo, R., Russell, L. M., Facchini, M. C., and Fuzzi, S.: Fog scavenging of organic and inorganic aerosol in the Po Valley, Atmos. Chem. Phys., 14, 6967-6981, https://doi.org/10.5194/acp14-6967-2014, 2014.

Hallquist, M., Wenger, J. C., Baltensperger, U., Rudich, Y., Simpson, D., Claeys, M., Dommen, J., Donahue, N. M., George, C., Goldstein, A. H., Hamilton, J. F., Herrmann, H., Hoffmann, T., Iinuma, Y., Jang, M., Jenkin, M. E., Jimenez, J. L., Kiendler-Scharr, A., Maenhaut, W., McFiggans, G., Mentel, Th. F., Monod, A., Prévôt, A. S. H., Seinfeld, J. H., Surratt, J. D., Szmigielski, R., and Wildt, J.: The formation, properties and impact of secondary organic aerosol: current and emerging issues, Atmos. Chem. Phys., 9, 5155-5236, https://doi.org/10.5194/acp9-5155-2009, 2009.

Hatch, L. E., Luo, W., Pankow, J. F., Yokelson, R. J., Stockwell, C. E., and Barsanti, K. C.: Identification and quantification of gaseous organic compounds emitted from biomass burning using two-dimensional gas chromatography-time-offlight mass spectrometry, Atmos. Chem. Phys., 15, 1865-1899, https://doi.org/10.5194/acp-15-1865-2015, 2015.

Hatch, L. E., Yokelson, R. J., Stockwell, C. E., Veres, P. R., Simpson, I. J., Blake, D. R., Orlando, J. J., and Barsanti, K. C.: Multi-instrument comparison and compilation of non-methane organic gas emissions from biomass burning and implications for smoke-derived secondary organic aerosol precursors, Atmos. Chem. Phys., 17, 1471-1489, https://doi.org/10.5194/acp17-1471-2017, 2017.

Hayes, P. L., Carlton, A. G., Baker, K. R., Ahmadov, R., Washenfelder, R. A., Alvarez, S., Rappenglück, B., Gilman, J. B., Kuster, W. C., de Gouw, J. A., Zotter, P., Prévôt, A. S. H., Szidat, S., Kleindienst, T. E., Offenberg, J. H., Ma, P. K., and Jimenez, J. L.: Modeling the formation and aging of secondary organic aerosols in Los Angeles during CalNex 2010, Atmos. Chem. Phys., 15, 5773-5801, https://doi.org/10.5194/acp-15-5773-2015, 2015.

Hildebrandt Ruiz, L. and Yarwood, G.: Interactions between organic aerosol and NOy: Influence on oxidant production, University of Texas at Austin, and ENVIRON International Corporation, Novato, California, USA, 2013.

Hodzic, A., Jimenez, J. L., Madronich, S., Canagaratna, M. R., DeCarlo, P. F., Kleinman, L., and Fast, J.: Modeling organic aerosols in a megacity: potential contribution of semi-volatile and intermediate volatility primary organic compounds to secondary organic aerosol formation, Atmos. Chem. Phys., 10, 5491-5514, https://doi.org/10.5194/acp-10-5491-2010, 2010.
Hodzic, A., Kasibhatla, P. S., Jo, D. S., Cappa, C. D., Jimenez, J. L., Madronich, S., and Park, R. J.: Rethinking the global secondary organic aerosol (SOA) budget: stronger production, faster removal, shorter lifetime, Atmos. Chem. Phys., 16, 7917-7941, https://doi.org/10.5194/acp-16-7917-2016, 2016.

Horowitz, L. W., Walters, S., Mauzerall, D. L., Emmons, L. K., Rasch, P. J., Granier, C., Tie, X. X., Lamarque, J. F., Schultz, M. G., Tyndall, G. S., Orlando, J. J., and Brasseur, G. P.: A global simulation of tropospheric ozone and related tracers: Description and evaluation of MOZART, version 2, J. Geophys. Res.-Atmos., 108, 4784, https://doi.org/10.1029/2002jd002853, 2003.

Jathar, S. H., Gordon, T. D., Hennigan, C. J., Pye, H. O. T., Pouliot, G., Adams, P. J., Donahue, N. M., and Robinson, A. L.: Unspeciated organic emissions from combustion sources and their influence on the secondary organic aerosol budget in the United States, P. Natl. Acad. Sci. USA, 111, 10473-10478, https://doi.org/10.1073/pnas.1323740111, 2014.

Jen, C. N., Hatch, L. E., Selimovic, V., Yokelson, R. J., Weber, R., Fernandez, A. E., Kreisberg, N. M., Barsanti, K. C., and Goldstein, A. H.: Speciated and total emission factors of particulate organics from burning western US wildland fuels and their dependence on combustion efficiency, Atmos. Chem. Phys., 19, 1013-1026, https://doi.org/10.5194/acp-19-1013-2019, 2019.

Jiang, J.: Source code of VBS-WLS box model and modified VBS module based on CAMx v6.5, Zenodo, https://doi.org/10.5281/zenodo.3998342, 2020.

Jiang, J.: Dataset for "Influence of biomass burning vapor wall loss correction on modeling organic aerosols in Europe by CAMx v6.50", Zenodo, https://doi.org/10.5281/zenodo.4267890, 2021.

Jiang, J., Aksoyoglu, S., Ciarelli, G., Oikonomakis, E., El-Haddad, I., Canonaco, F., O’Dowd, C., Ovadnevaite, J., Minguillón, M. C., Baltensperger, U., and Prévôt, A. S. H.: Effects of two different biogenic emission models on modelled ozone and aerosol concentrations in Europe, Atmos. Chem. Phys., 19, 3747-3768, https://doi.org/10.5194/acp-19-3747-2019, 2019a.

Jiang, J., Aksoyoglu, S., El-Haddad, I., Ciarelli, G., Denier van der Gon, H. A. C., Canonaco, F., Gilardoni, S., Paglione, M., Minguillón, M. C., Favez, O., Zhang, Y., Marchand, N., Hao, L., Virtanen, A., Florou, K., O’Dowd, C., Ovadnevaite, J., Baltensperger, U., and Prévôt, A. S. H.: Sources of organic aerosols in Europe: a modeling study using CAMx with modified volatility basis set scheme, Atmos. Chem. Phys., 19, 15247-15270, https://doi.org/10.5194/acp-19-15247-2019, 2019 b.

Jimenez, J. L., Canagaratna, M. R., Donahue, N. M., Prevot, A. S. H., Zhang, Q., Kroll, J. H., DeCarlo, P. F., Allan, J. D., Coe, H., Ng, N. L., Aiken, A. C., Docherty, K. S., Ulbrich, I. M., Grieshop, A. P., Robinson, A. L., Duplissy, J., Smith, J. D., Wilson, K. R., Lanz, V. A., Hueglin, C., Sun, Y. L., Tian, J., Laaksonen, A., Raatikainen, T., Rautiainen, J., Vaattovaara, P., Ehn, M., Kulmala, M., Tomlinson, J. M., Collins, D. R., Cubison, M. J., Dunlea, E. J., Huffman, J. A., Onasch, T. B., Alfarra, M. R., Williams, P. I., Bower, K., Kondo, Y., Schneider, J., Drewnick, F., Borrmann, S., Weimer, S., Demerjian, K., Salcedo, D., Cottrell, L., Griffin, R., Takami, A., Miyoshi, T., Hatakeyama, S., Shimono, A., Sun, J. Y., Zhang, Y. M., Dzepina, K., Kimmel, J. R., Sueper, D., Jayne, J. T., Herndon, S. C., Trimborn, A. M., Williams, L. R., Wood, E. C., Middlebrook, A. M., Kolb, C. E., Baltensperger, U., and Worsnop, D. R.: Evolution of Or- 
ganic Aerosols in the Atmosphere, Science, 326, 1525-1529, https://doi.org/10.1126/science.1180353, 2009.

Kanakidou, M., Seinfeld, J. H., Pandis, S. N., Barnes, I., Dentener, F. J., Facchini, M. C., Van Dingenen, R., Ervens, B., Nenes, A., Nielsen, C. J., Swietlicki, E., Putaud, J. P., Balkanski, Y., Fuzzi, S., Horth, J., Moortgat, G. K., Winterhalter, R., Myhre, C. E. L., Tsigaridis, K., Vignati, E., Stephanou, E. G., and Wilson, J.: Organic aerosol and global climate modelling: a review, Atmos. Chem. Phys., 5, 1053-1123, https://doi.org/10.5194/acp-5-10532005, 2005.

Koo, B., Knipping, E., and Yarwood, G.: 1.5-Dimensional volatility basis set approach for modeling organic aerosol in CAMx and CMAQ, Atmos. Environ., 95, 158-164, https://doi.org/10.1016/j.atmosenv.2014.06.031, 2014.

Koss, A. R., Sekimoto, K., Gilman, J. B., Selimovic, V., Coggon, M. M., Zarzana, K. J., Yuan, B., Lerner, B. M., Brown, S. S., Jimenez, J. L., Krechmer, J., Roberts, J. M., Warneke, C., Yokelson, R. J., and de Gouw, J.: Non-methane organic gas emissions from biomass burning: identification, quantification, and emission factors from PTR-ToF during the FIREX 2016 laboratory experiment, Atmos. Chem. Phys., 18, 3299-3319, https://doi.org/10.5194/acp-18-3299-2018, 2018.

Krechmer, J. E., Pagonis, D., Ziemann, P. J., and Jimenez, J. L.: Quantification of gas-wall partitioning in teflon environmental chambers using rapid bursts of low-volatility oxidized species generated in situ, Environ. Sci. Technol., 50, 5757-5765, https://doi.org/10.1021/acs.est.6b00606, 2016.

Kuenen, J. J. P., Visschedijk, A. J. H., Jozwicka, M., and Denier van der Gon, H. A. C.: TNO-MACC_II emission inventory; a multi-year (2003-2009) consistent high-resolution European emission inventory for air quality modelling, Atmos. Chem. Phys., 14, 10963-10976, https://doi.org/10.5194/acp-14-109632014, 2014.

Lelieveld, J., Evans, J. S., Fnais, M., Giannadaki, D., and Pozzer, A.: The contribution of outdoor air pollution sources to premature mortality on a global scale, Nature, 525, 367-371, https://doi.org/10.1038/nature15371, 2015.

Lim, C. Y., Hagan, D. H., Coggon, M. M., Koss, A. R., Sekimoto, K., de Gouw, J., Warneke, C., Cappa, C. D., and Kroll, J. H.: Secondary organic aerosol formation from the laboratory oxidation of biomass burning emissions, Atmos. Chem. Phys., 19, 12797 12809, https://doi.org/10.5194/acp-19-12797-2019, 2019.

Loza, C. L., Chan, A. W. H., Galloway, M. M., Keutsch, F. N., Flagan, R. C., and Seinfeld, J. H.: Characterization of Vapor Wall Loss in Laboratory Chambers, Environ. Sci. Technol., 44, 50745078, https://doi.org/10.1021/es100727v, 2010.

Lu, Q., Zhao, Y., and Robinson, A. L.: Comprehensive organic emission profiles for gasoline, diesel, and gas-turbine engines including intermediate and semi-volatile organic compound emissions, Atmos. Chem. Phys., 18, 17637-17654, https://doi.org/10.5194/acp-18-17637-2018, 2018.

Matsunaga, A. and Ziemann, P. J.: Gas-wall partitioning of organic compounds in a teflon film chamber and potential effects on reaction product and aerosol yield measurements, Aerosol Sci. Tech., 44, 881-892, https://doi.org/10.1080/02786826.2010.501044, 2010.

May, A. A., Levin, E. J. T., Hennigan, C. J., Riipinen, I., Lee, T., Collett, J. L., Jimenez, J. L., Kreidenweis, S. M., and Robinson, A. L.: Gas-particle partitioning of primary organic aerosol emissions: 3. Biomass burning, J. Geophys. Res.-Atmos., 118 , 11327-11338, 2013.

Meroni, A., Pirovano, G., Gilardoni, S., Lonati, G., Colombi, C., Gianelle, V., Paglione, M., Poluzzi, V., Riva, G. M., and Toppetti, A.: Investigating the role of chemical and physical processes on organic aerosol modelling with CAMx in the Po Valley during a winter episode, Atmos. Environ., 171, 126-142, https://doi.org/10.1016/j.atmosenv.2017.10.004, 2017.

Mitchell, M.: An introduction to genetic algorithms, The MIT Press, Cambridge, Massachusetts, USA, London, UK, 1996.

NCAR: The Tropospheric Visible and Ultraviolet (TUV) Radiation Model web page, National Center for Atmospheric Research, Atmospheric Chemistry Division, Boulder, Colorado, USA, 2011.

Nenes, A., Pandis, S. N., and Pilinis, C.: ISORROPIA: A new thermodynamic equilibrium model for multiphase multicomponent inorganic aerosols, Aquat. Geochem., 4, 123-152, https://doi.org/10.1023/a:1009604003981, 1998.

Oderbolz, D. C., Aksoyoglu, S., Keller, J., Barmpadimos, I., Steinbrecher, R., Skjøth, C. A., Plaß-Dülmer, C., and Prévôt, A. S. H.: A comprehensive emission inventory of biogenic volatile organic compounds in Europe: improved seasonality and land-cover, Atmos. Chem. Phys., 13, 1689-1712, https://doi.org/10.5194/acp13-1689-2013, 2013.

Paglione, M., Gilardoni, S., Rinaldi, M., Decesari, S., Zanca, N., Sandrini, S., Giulianelli, L., Bacco, D., Ferrari, S., Poluzzi, V., Scotto, F., Trentini, A., Poulain, L., Herrmann, H., Wiedensohler, A., Canonaco, F., Prévôt, A. S. H., Massoli, P., Carbone, C., Facchini, M. C., and Fuzzi, S.: The impact of biomass burning and aqueous-phase processing on air quality: a multiyear source apportionment study in the Po Valley, Italy, Atmos. Chem. Phys., 20, 1233-1254, https://doi.org/10.5194/acp20-1233-2020, 2020.

Pankow, J. F.: An absorption model of gas/particle partitioning of organic compounds in the atmosphere, Atmos. Environ., 28 , 185-188, https://doi.org/10.1016/1352-2310(94)90093-0, 1994.

Qi, L., Chen, M., Stefenelli, G., Pospisilova, V., Tong, Y., Bertrand, A., Hueglin, C., Ge, X., Baltensperger, U., Prévôt, A. S. H., and Slowik, J. G.: Organic aerosol source apportionment in Zurich using an extractive electrospray ionization time-of-flight mass spectrometer (EESI-TOF-MS) - Part 2: Biomass burning influences in winter, Atmos. Chem. Phys., 19, 8037-8062, https://doi.org/10.5194/acp-19-8037-2019, 2019.

Ramboll: User's guide: the Comprehensive Air Quality Model with extensions (CAMx) version 6.5, Ramboll, California, USA 2018.

Robinson, A. L., Donahue, N. M., Shrivastava, M. K., Weitkamp, E. A., Sage, A. M., Grieshop, A. P., Lane, T. E., Pierce, J. R., and Pandis, S. N.: Rethinking organic aerosols: semivolatile emissions and photochemical aging, Science, 315, 1259-1262, https://doi.org/10.1126/science.1133061, 2007.

Sekimoto, K., Koss, A. R., Gilman, J. B., Selimovic, V., Coggon, M. M., Zarzana, K. J., Yuan, B., Lerner, B. M., Brown, S. S., Warneke, C., Yokelson, R. J., Roberts, J. M., and de Gouw, J.: High- and low-temperature pyrolysis profiles describe volatile organic compound emissions from western US wildfire fuels, Atmos. Chem. Phys., 18, 9263-9281, https://doi.org/10.5194/acp18-9263-2018, 2018.

Shrivastava, M., Fast, J., Easter, R., Gustafson Jr., W. I., Zaveri, R. A., Jimenez, J. L., Saide, P., and Hodzic, A.: Modeling or- 
ganic aerosols in a megacity: comparison of simple and complex representations of the volatility basis set approach, Atmos. Chem. Phys., 11, 6639-6662, https://doi.org/10.5194/acp11-6639-2011, 2011.

Skamarock, W. C., Klemp, J. B., Dudhia, J., Gill, D. O., Barker, D. M., Duda, M. G., Huang, X.-Y., Wang, W., and Powers, J. G.: A Description of the Advanced Research WRF Version 3, Mesoscale and Microscale Meteorology Division, National Center for Atmospheric Research, Boulder, Colorado, USA, 2008.

Stefenelli, G., Jiang, J., Bertrand, A., Bruns, E. A., Pieber, S. M., Baltensperger, U., Marchand, N., Aksoyoglu, S., Prévôt, A. S. H., Slowik, J. G., and El Haddad, I.: Secondary organic aerosol formation from smoldering and flaming combustion of biomass: a box model parametrization based on volatility basis set, Atmos. Chem. Phys., 19, 11461-11484, https://doi.org/10.5194/acp-1911461-2019, 2019.

Theodoritsi, G. N. and Pandis, S. N.: Simulation of the chemical evolution of biomass burning organic aerosol, Atmos. Chem. Phys., 19, 5403-5415, https://doi.org/10.5194/acp-195403-2019, 2019.

Tsimpidi, A. P., Karydis, V. A., Zavala, M., Lei, W., Molina, L., Ulbrich, I. M., Jimenez, J. L., and Pandis, S. N.: Evaluation of the volatility basis-set approach for the simulation of organic aerosol formation in the Mexico City metropolitan area, Atmos. Chem. Phys., 10, 525-546, https://doi.org/10.5194/acp-10-5252010, 2010.
Woody, M. C., West, J. J., Jathar, S. H., Robinson, A. L., and Arunachalam, S.: Estimates of non-traditional secondary organic aerosols from aircraft SVOC and IVOC emissions using CMAQ, Atmos. Chem. Phys., 15, 6929-6942, https://doi.org/10.5194/acp-15-6929-2015, 2015.

Woody, M. C., Baker, K. R., Hayes, P. L., Jimenez, J. L., Koo, B., and Pye, H. O. T.: Understanding sources of organic aerosol during CalNex-2010 using the CMAQ-VBS, Atmos. Chem. Phys., 16, 4081-4100, https://doi.org/10.5194/acp16-4081-2016, 2016.

Zhang, X., Cappa, C. D., Jathar, S. H., McVay, R. C., Ensberg, J. J., Kleeman, M. J., and Seinfeld, J. H.: Influence of vapor wall loss in laboratory chambers on yields of secondary organic aerosol, P. Natl. Acad. Sci. USA, 111, 5802-5807, https://doi.org/10.1073/pnas.1404727111, 2014.

Zhang, Y., Favez, O., Petit, J.-E., Canonaco, F., Truong, F., Bonnaire, N., Crenn, V., Amodeo, T., Prévôt, A. S. H., Sciare, J., Gros, V., and Albinet, A.: Six-year source apportionment of submicron organic aerosols from near-continuous highly timeresolved measurements at SIRTA (Paris area, France), Atmos. Chem. Phys., 19, 14755-14776, https://doi.org/10.5194/acp-1914755-2019, 2019. 